\title{
57. DATA REPORT: GEOCHEMICAL WELL LOGS THROUGH CENOZOIC AND QUATERNARY SEDIMENTS FROM SITES 815, 817, 820, 822, AND 823 ${ }^{1}$
}

\author{
Elizabeth Lewis Pratson, ${ }^{2}$ Cristina Broglia, ${ }^{2}$ and Richard Jarrard ${ }^{3}$
}

\begin{abstract}
Geochemical well logs were obtained through sediments at Sites $815,817,820,822$, and 823 of Leg 133. Corrections have been applied to the logs to account for variations in hole size, drilling-fluid composition, and drill-pipe attenuation. Oxide and calcium carbonate weight percentages have been calculated from the processed logs and are compared with the available carbonate measurements from core. Log-derived $\mathrm{CaCO}_{3}$ measurements correlate well with shipboard $\mathrm{CaCO}_{3}$ core-derived measurements in each of the logged open-hole intervals.
\end{abstract}

\section{INTRODUCTION}

Drilling during Leg 133 took place along the major platforms and basins off the coast of northeastern Australia (Fig. 1). The primary objectives of the leg were defining the evolution of these platforms and their relationship to the adjoining basins and understanding the effects of sea level and climate changes in these physiographic-structural provinces. Sixteen sites, forming two transects across the platforms and basins, were drilled during Leg 133. The first transect extends from the outer shelf and slope of the Great Barrier Reef (Sites 819 through 822), into the Queensland Trough (Site 823), and onto the Queensland Plateau (Sites 811/825 and 824). The second transect extends north from the edge of the Marion Plateau (Sites 815, 816, and 826), across the Townsville Trough, and into the slope of the Queensland Plateau (Sites 812 through 814) (Shipboard Scientific Party, 1991b, 1991c, 1991d).

Five of the drilled sites (Sites 815, 817, 820, 822, and 823) were logged with the geochemical tool. The geochemical tool string measures the major elements of a formation at intervals of $0.1524 \mathrm{~m}$. The geochemical data provide a record of the rock chemistry that is invaluable for the sites of Leg 133, especially where core recovery was poor.

This report describes the hole conditions and logging operations at each site logged with the geochemical tool, presents the basic principles of the geochemical tool string, explains the data processing techniques, and compares the processed natural gamma-ray and oxide/calcium carbonate measurements estimated from the logs with the lithologic descriptions of core and the available core measurements.

\section{DATA ACQUISITION}

\section{Site 815}

Hole $815 \mathrm{~A}$ penetrated $474 \mathrm{~m}$ of the margin of the Townsville Trough. Core recovery was good in this hole, averaging $87 \%$. A wiper trip and a 30-bbl mud sweep to condition and clean the hole for logging were made in Hole $815 \mathrm{~A}$.

A standard suite of logs was planned for Site 815; problems with the Schlumberger data acquisition system, however, limited logging in the hole to two incomplete passes. The seismic stratigraphic

\footnotetext{
'McKenzie, J.A., Davies, P.J., Palmer-Julson, A., 1993. Proc. ODP, Sci. Results, 133: College Station, TX (Ocean Drilling Program).

${ }^{2}$ Borehole Research Group, Lamont-Doherty Geological Observatory of Columbia University, Palisades, NY 10964, U.S.A.

${ }^{3}$ Dept. of Geology and Geophysics, College of Mines and Earth Sciences, 717 W.C. Browning Building, University of Utah, Salt Lake City, UT 84112-1183, U.S.A.
}

combination tool string (consisting of the telemetry, dual induction resistivity, lithodensity, sonic, and natural gamma-ray tools) obtained data from 133 to 424 mbsf in Hole $815 \mathrm{~A}$, with a complete pass down and an incomplete pass up the interval. The logs were satisfactory, except for those from the downgoing density log, where the tool was unable to maintain continuous pad contact with the borehole wall (Shipboard Scientific Party, 1991e). Also in this hole, a short pass from 256 to 319 mbsf was made with the geochemical tool string (consisting of the gamma-ray spectroscopy, aluminum clay, and natural gamma-ray tools); this logging pass, however, was cut short because of continued Schlumberger computer problems.

\section{Site $\mathbf{8 1 7}$}

Drilling at Site 817 penetrated $700 \mathrm{~m}$ of platform slope sediments on the northern side of the Townsville Trough and on the lower slope of the Queensland Plateau. Hole 817A was drilled with the advanced hydraulic piston corer (APC) to $215 \mathrm{mbsf}$, with $103.9 \%$ recovery, and cored with the extended core barrel (XCB) to $331 \mathrm{mbsf}$, with $50 \%$ recovery. Hole 817B was drilled with the APC from 0 to $204 \mathrm{mbsf}$, with $103.9 \%$ recovery. Hole $817 \mathrm{C}$ was also drilled with the APC to 27 mbsf, with $100.2 \%$ recovery. Hole $817 \mathrm{D}$ was washed to $270 \mathrm{mbsf}$ and then drilled with the rotary core barrel (RCB) to $700 \mathrm{mbsf}$, with $5.2 \%$ recovery. This last hole was cleaned, and pipe was pulled to 106 mbsf for logging.

Four logging tool strings were run in Hole 817D. The first string was the seismic stratigraphic logging tool, which recorded data from 63 to $678 \mathrm{mbsf}$. The geochemical tool string was run next from the seafloor to $683 \mathrm{mbsf}$. The formation microscanner tool string, which consists of the formation microscanner, general purpose inclinometer, and natural gamma-ray tools, was run third and was followed by an unsuccessful attempt to obtain a vertical seismic profile with the well seismic tool (Shipboard Scientific Party, 1991f).

\section{Site 820}

Site 820 is the central site in a transect of three sites $(819,820$, and 821 ) along the slope of the Queensland Plateau. Hole $820 \mathrm{~A}$ was drilled first with the APC to $140 \mathrm{mbsf}$, with $102.5 \%$ recovery, and then with the vibrating piston corer (VPC) to $144 \mathrm{mbsf}$, with $49.5 \%$ recovery. Similarly, Hole $820 \mathrm{~B}$ was drilled with the APC to $160 \mathrm{mbsf}$, with $100.7 \%$ recovery, and then with the XCB to $400 \mathrm{mbsf}$, with $68.2 \%$ recovery. A short wiper trip was made to clean the hole, and then pipe was pulled to $104 \mathrm{mbsf}$ for logging.

The same four standard logging strings that were run in Hole 817D were also run in Hole $820 \mathrm{~B}$. The first logging string, the seismic 


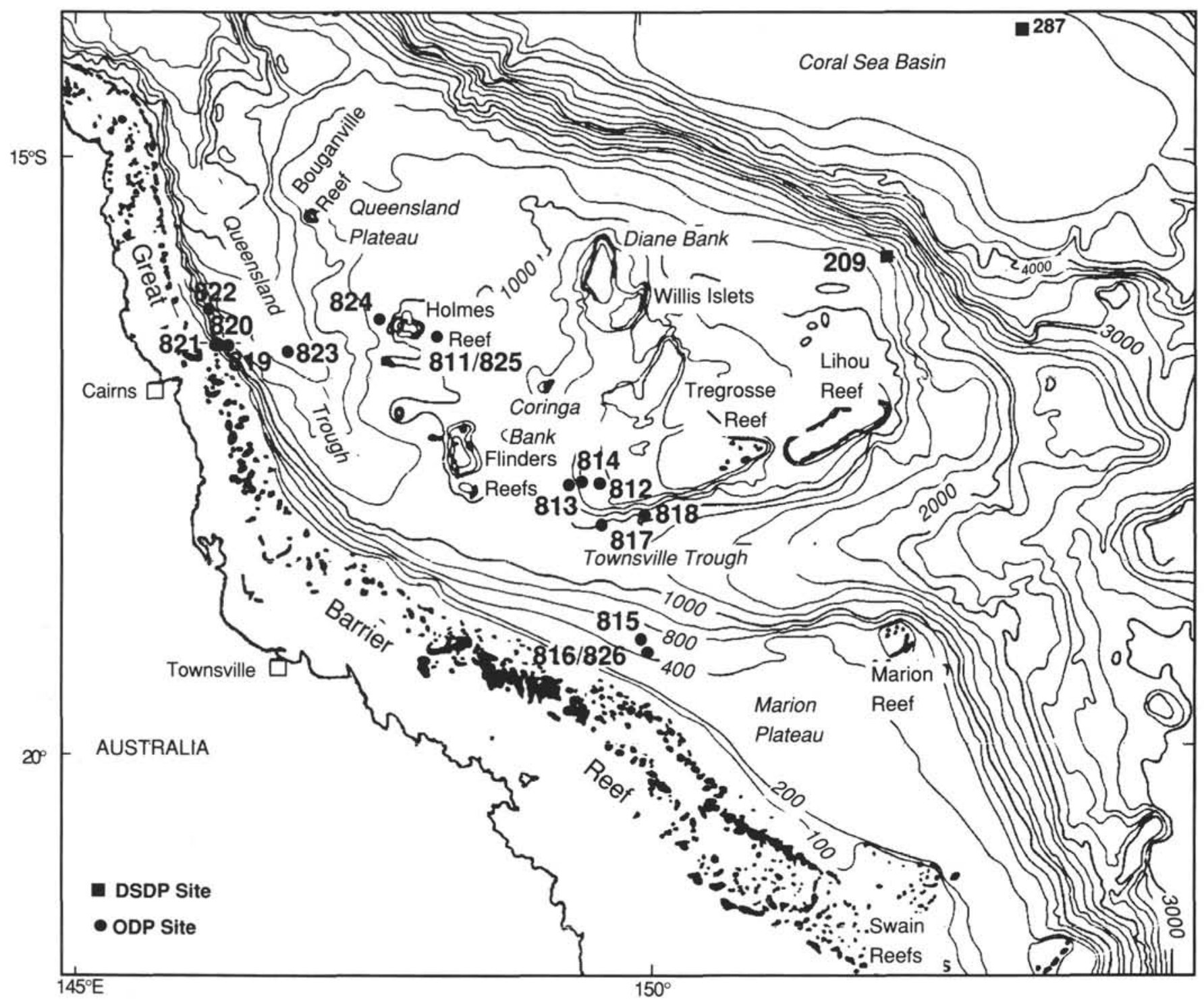

Figure 1. Map of Leg 133 drill sites and prior DSDP drill sites, northeastern Australian margin (Shipboard Scientific Party, 1991a, fig. 1).

stratigraphic, gathered data from 74 to 381 mbsf. The geochemical tool string, run next, recorded data from the seafloor to $360 \mathrm{mbsf}$. The formation microscanner was run in the open-hole section down to $360 \mathrm{mbsf}$, and was once again followed by an unsuccessful attempt to run the vertical seismic profile tool (Shipboard Scientific Party, 1991g).

\section{Site 822}

Site 822 was drilled on the foot of the slope of the Great Barrier Reef. Hole $822 \mathrm{~A}$ was drilled with the APC to 96 mbsf, with $106.3 \%$ recovery, and then drilled with the XCB to $400 \mathrm{mbsf}$, with $80.3 \%$ recovery. A short wiper trip was made to clear the hole, and then the hole was washed and reamed to the bottom. Pipe was pulled to 103 mbsf in preparation for logging.

Three logging strings were run successfully in Hole $822 \mathrm{~A}$; however, bottom infill prevented logging in the bottom of the hole. The first logging string, the seismic stratigraphic tool string, was run from 66 to $324 \mathrm{mbsf}$ and was followed by the geochemical tool string, run from the seafloor to $321 \mathrm{mbsf}$, and then by the formation microscanner, run only from 83 to $180 \mathrm{mbsf}$, because of a bridge encountered at 182 mbsf (Shipboard Scientific Party, 1991h).

\section{Site 823}

Site 823 , located in the Queensland Trough, was drilled as a basinal site. Hole $823 \mathrm{~A}$ was drilled with the APC to $120 \mathrm{mbsf}$, with $103.3 \%$ recovery. Hole $823 \mathrm{~B}$ was also drilled with the APC to $113 \mathrm{mbsf}$, with $104.3 \%$ recovery, and with the XCB to $805 \mathrm{mbsf}$, with $92 \%$ recovery. Hole $823 \mathrm{C}$ was washed down to $784 \mathrm{mbsf}$ and drilled with the RCB to 1011 mbsf, with $82 \%$ recovery. A short wiper trip was made in this last hole to clear it for logging, after which the pipe was pulled to $107.7 \mathrm{mbsf}$.

The same three tool strings run in Hole $822 \mathrm{~A}$ were also run in Hole $823 \mathrm{C}$. The seismic stratigraphic tool string recorded data from 101 to 976 mbsf. The geochemical tool string ran from the seafloor to 975 mbsf. The formation microscanner was run in the open-hole interval to 945 mbsf (Shipboard Scientific Party, 1991i).

\section{GEOCHEMICAL TOOL STRING}

The geochemical logging tool string (GLT) consists of four logging tools: the natural gamma-ray tool (NGT), the compensated neutron tool (CNT), the aluminum activation clay tool (AACT), and the gamma-ray 


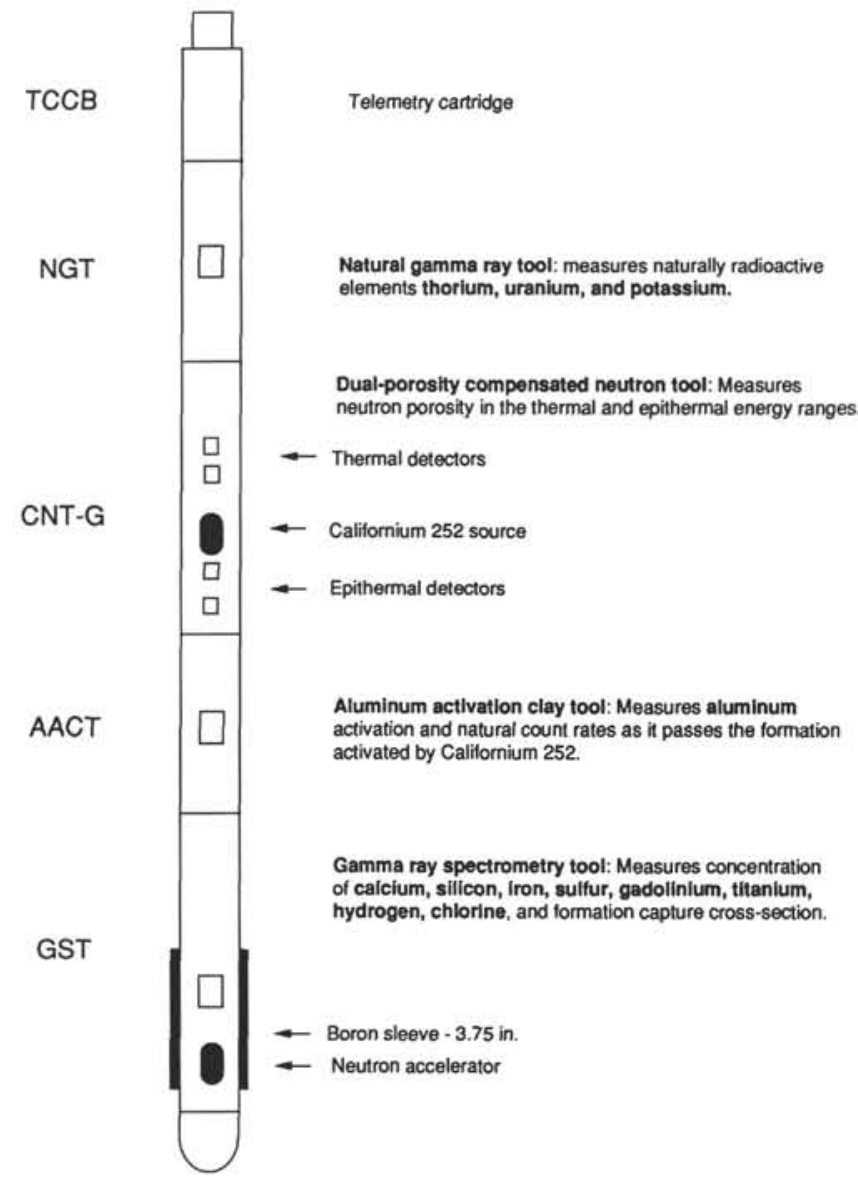

Figure 2. Schematic drawing of the geochemical logging string used in the Ocean Drilling Program.

spectrometry tool (GST) (GLT, NGT, CNT, AACT, and GST are trademarks of Schlumberger; Fig. 2). The natural gamma-ray tool is located at the top of the tool string, so that it can measure the naturally occurring radionuclides, $\mathrm{Th}, \mathrm{U}$, and $\mathrm{K}$, before the formation is irradiated by the nuclear sources contained in the lower tools. Below the natural gamma-ray tool is the compensated neutron tool, which carries low-energy californium-252 $\left({ }^{252} \mathrm{Cf}\right)$ to activate the aluminum atoms in the formation. The $\mathrm{Al}$ activation clay tool, a modified NGT, is located below the ${ }^{252} \mathrm{Cf}$ source, measuring the activated gamma rays in the formation. By combining the AACT measurement with the previous NGT measurement, the background radiation is subtracted out and a reading of formation $\mathrm{Al}$ is obtained (Scott and Smith, 1973). The gamma-ray spectrometry tool, at the base of the string, carries a pulsed neutron generator to induce capture gamma-ray reactions in the borehole and formation and an $\mathrm{NaI}(\mathrm{T} 1)$ scintillation detector to measure the spectrum of gamma rays generated by neutron capture reactions. Because each of the elements in the formation is characterized by a unique spectral signature, it is possible to derive the contribution (or yield) of each of the major elements silicon ( $\mathrm{Si}$ ), iron ( $\mathrm{Fe}$ ), calcium $(\mathrm{Ca})$, titanium (Ti), sulfur $(\mathrm{S})$, gadolinium $(\mathrm{Gd})$, and potassium $(\mathrm{K})$ to the measured spectrum and, in turn, to estimate the relative abundance of each in the formation. The GST also measures the hydrogen $(\mathrm{H})$ and chlorine $(\mathrm{Cl})$ in the borehole and formation, but these elements are not used for determining rock geochemistry.

The only major rock-forming elements not measured by the geochemical tool string are magnesium $(\mathrm{Mg})$ and sodium $(\mathrm{Na})$; the neutron-capture cross sections of these elements are too small relative to their typical abundances for the tool string to detect them. A rough
Table 1. Oxide/carbonate factors used in normalizing elements to $100 \%$ and in converting elements to oxides.

\begin{tabular}{ccc}
\hline Element & Oxide/carbonate & Conversion factor \\
\hline $\mathrm{Si}$ & $\mathrm{SiO}_{2}$ & 2.139 \\
$\mathrm{Ca}$ & $\mathrm{CaCO}_{3}$ & 2.497 \\
$\mathrm{Fe}$ & $\mathrm{FeO}($ total Fe) & 1.358 \\
$\mathrm{~K}$ & $\mathrm{~K}_{2} \mathrm{O}$ & 1.205 \\
$\mathrm{Ti}$ & $\mathrm{TiO}_{2}$ & 1.668 \\
$\mathrm{Al}$ & $\mathrm{Al}_{2} \mathrm{O}_{3}$ & 1.889 \\
\hline
\end{tabular}

estimate of $\mathrm{Mg}+\mathrm{Na}$ can, in theory, be made using the photoelectric factor (PEF), measured by the lithodensity tool. This measured PEF is compared with a calculated PEF (a summation of the PEF from all the measured elements). The separation between the measured and calculated PEFs is, in theory, attributable to any element left over in the formation (i.e., Mg and Na; Fig. 3; Hertzog et al., 1989).

Calculation of the $\mathrm{Mg}$ content was attempted in Hole $817 \mathrm{D}$, but the results seem to be governed more by the hole conditions than by variations in the content of $\mathrm{Mg}$ or $\mathrm{Na}$ (Fig. 4). Hole 817D was logged through a reef, which, according to the sparse core recovered, showed progressive dolomitization below $430 \mathrm{mbsf}$. The calculated $\mathrm{Mg}$ curve (track 1) points out a few "dolomitized" zones between $300 \mathrm{mbsf}$ and the bottom of the hole; upon comparison with other logs, however, we see that most of the $\mathrm{Mg}$ peaks occur where the hole has been washed out, as the caliper and DRHO curves indicate (DRHO is the bulk density correction for hole size automatically performed during the recording). The PEF of both water and $\mathrm{Mg}$ is low, compared to the other rock-forming elements; therefore, wherever the hole is enlarged, the results overestimate the $\mathrm{Mg}$ content.

One interval is found at $610 \mathrm{mbsf}$, however, where the calculation seems to yield reliable results. The hole is relatively in gauge in this zone, and corresponding highs are found in the resistivity and uranium logs, as would be expected in a dolomitized zone. The formation microscanner (FMS) images in this zone also support the presence of $\mathrm{Mg}$; large round features, too large to be interpreted as burrows, may represent vugs, typical of dolomitized lithologies.

From the attempted $\mathrm{Mg}$ calculation in this well, we concluded that it is accurate only where hole conditions are good. Therefore, because hole conditions during Leg 133 were generally poor, we did not include the $\mathrm{Mg}$ curve in the normalization with the other elements.

\section{DATA REDUCTION}

The well-log data from the Schlumberger tools are transmitted digitally up a wireline and are recorded and processed on the JOIDES Resolution in the Schlumberger Cyber Service Unit (CSU). The results from the CSU are made available as "field logs" for initial, shipboard interpretation. Subsequent reprocessing is necessary to correct the data for the effects of fluids added to the well, logging speed changes, and pipe interference. Processing of the spectroscopy data is required to transform the relative elemental yields into oxide weight fractions.

The processing is performed with a set of log-interpretation programs written by Schlumberger that have been slightly modified to work in the lithologies encountered in ODP holes. The steps are summarized below:

\section{Reconstruction of Relative Elemental Yields from Recorded Spectral Data}

This first processing step uses a weighted, least-squares method to compare the measured spectra from the geochemical spectroscopy tool with a series of standard spectra to determine the relative contribution (or yield) of each element. Whereas six elemental standards 

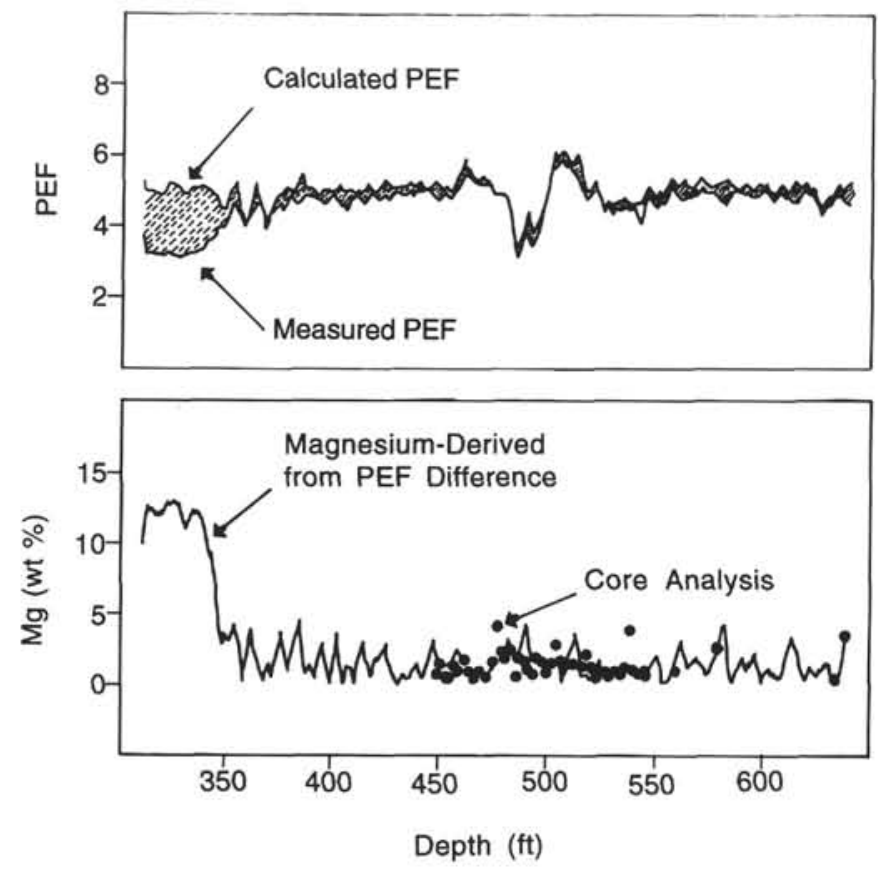

Figure 3. Comparison of the measured value of photoelectric effect (PEF) with the one calculated from the geochemical tool string in an oilfield well (Hertzog et al., 1989). The calculated $\mathrm{Mg}$ agrees well with core measurements. A dolomitic zone is inferred from the logs in the upper part of the hole; no core data, however, are available from this interval to confirm the accuracy of the $\mathrm{Mg}$ calculation.

( $\mathrm{Si}, \mathrm{Fe}, \mathrm{Ca}, \mathrm{S}, \mathrm{Cl}$, and $\mathrm{H}$ ) are used to produce the shipboard yields, three additional standards ( $\mathrm{Ti}, \mathrm{Gd}$, and $\mathrm{K}$ ) can be included in the shore-based processing to improve the fit of the spectral standards to the measured spectra (Grau and Schweitzer, 1989). These additional three standards cannot be included on board the ship because of limited processing power. Although these additional elements often appear in the formation in very low concentrations, they can make a large contribution to the measured spectra because they have large neutron-capture cross sections. For example, the capture cross section of $\mathrm{Gd}$ is 49,000 barns; that of $\mathrm{Si}$ is 0.16 barns (Hertzog et al., 1989). Therefore, although occurring in very small abundances in the formation, Gd is included in the calculation of a best fit between the measured and the standard spectra.

This best-fit analysis was performed in each of the logged holes to include spectral standards for $\mathrm{Si}, \mathrm{Ca}, \mathrm{Fe}, \mathrm{Ti}, \mathrm{Gd}, \mathrm{H}$, and $\mathrm{Cl}$. The spectral standard for $\mathrm{K}$ was not included in this step because its concentrations existed below the resolution of the GST tool, and including K would have significantly increased the noise level of all the other yields. Because the K measurement from the NGT is a much better measurement of $\mathrm{K}$, we use it in the later normalization step. When processing data from ODP wells, we have found that it is best to omit $\mathrm{K}$ from the spectral reconstruction step when $\mathrm{K}$ concentrations are low. The $\mathrm{S}$ yield was included in this best-fit analysis step, but not included later in the normalization step; we found that the small amount of S signal was from the borehole and not from the formation itself. The Si yield was not included in the best-fit analysis for Hole $817 \mathrm{D}$, as its concentrations in this particular well were below the resolution of the tool. A straight, seven-point smoothing filter was applied to all the yields in each of the holes to reduce the noise in the data.

\section{Depth Shifting}

Geochemical processing involves the integration of data from the different tool strings; consequently, all the data must be depth corre- lated to one reference logging run. An NGT, run on each of the logging tool strings, provides a spectral gamma-ray curve with which to correlate each of the logging runs. A reference run is chosen based on the amount of cable tension, the rate of cable speed (tools run at faster speeds are less likely to stick), and the overall quality of the logs. The seismic stratigraphic tool string was chosen as the reference run in Holes $815 \mathrm{~A}, 822 \mathrm{~A}$, and $823 \mathrm{C}$; the geochemical tool string was used as the reference run in Holes 817D and 820B.

The depth-shifting procedure involves picking a number of reference points and then using a program that stretches and squeezes the matching logging run to fit the reference logging run. A detailed summary of the depth shifts can be obtained by contacting the Borehole Research Group.

\section{Calculation of Total Radioactivity and Th, $U$, and $K$ Concentrations}

The third processing routine calculates the total natural gamma radiation, as well as concentrations of $\mathrm{Th}, \mathrm{U}$, and $\mathrm{K}$ in the formation, using the counts in five spectral windows from the natural gammaray tool (Lock and Hoyer, 1971). This routine resembles shipboard processing, except that corrections for hole-size changes are made in the shore-based processing of these curves. A Kalman filtering (Ruckebusch, 1983) is used at sea to minimize the statistical uncertainties in the logs, which would otherwise create erroneous negative readings and anti-correlations (especially between Th and $\mathrm{U}$ ). An alpha filter, recently introduced by Schlumberger for shore-based processing, strongly filters the raw spectral curves but keeps the total gamma-ray curve unsmoothed before calculating out the Th, U, and K (C. Flaum, pers. comm., 1988). At each depth level, calculations and corrections also were made for $\mathrm{K}$ contained in the mud. The $\mathrm{K}$ correction is particularly useful where $\mathrm{K}$-bearing muds are routinely added to the hole; however, because of dispersion, it is difficult to know exactly how much $\mathrm{K}$ is actually in the borehole. The outputs of this program are $\mathrm{K}$ (wet wt\%), $\mathrm{U}$ (ppm), and Th (ppm), along with a total gamma-ray curve and a computed gamma-ray curve (total gamma ray minus $\mathrm{U}$ contribution).

\section{Calculation of Al Concentration}

The fourth processing routine calculates an $\mathrm{Al}$ curve using four energy windows and concurrently corrects for natural radioactivity, borehole-fluid neutron-capture cross section, formation neutron-capture cross section, formation slowing-down length, and borehole size. Porosity and density logs are needed in this routine to convert the wet-weight percentages of $\mathrm{K}$ and $\mathrm{Al}$ curves to dry-weight percentages.

Density logs were used in the processing of Holes $815 \mathrm{~A}, 817 \mathrm{D}$, $820 \mathrm{~B}$, and $823 \mathrm{C}$; however, interpolated core values were used in Hole $822 \mathrm{~A}$, where the poor hole conditions resulted in unreliable density logs (Shipboard Scientific Party, 1991h, "Downhole Measurements" section). Porosity logs are recorded on the geochemical tool; these measurements are uncalibrated, though, because a stronger $\mathrm{Cf}$ source was used in place of the typical americium-beryllium (AmBe) source in the neutron tool. Porosity logs were, therefore, either derived from interpolated core values (Hole $822 \mathrm{~A}$ ) or calculated from the density logs using the following equation:

$$
P H I T=(\text { RHOM }- \text { RHOB }) /(\text { RHOM }- \text { RHOF }),
$$

where $P H I T=$ percentage porosity, $R H O M=$ matrix density, obtained from core measurements in $\mathrm{g} / \mathrm{cm}^{3}, R H O B=$ bulk density from the log in $\mathrm{g} / \mathrm{cm}^{3}$, and $R H O F=$ density of fluid $=1.05 \mathrm{~g} / \mathrm{cm}^{3}$.

A correction is also made for $\mathrm{Si}$ interference with $\mathrm{Al}$; the ${ }^{252} \mathrm{Cf}$ source activates the $\mathrm{Si}$, producing the aluminum isotope ${ }^{28} \mathrm{Al}$ (Hertzog et al., 1989). The program uses the $\mathrm{Si}$ yield from the gamma-ray spectroscopy tool to determine the Si background correction. The pro- 


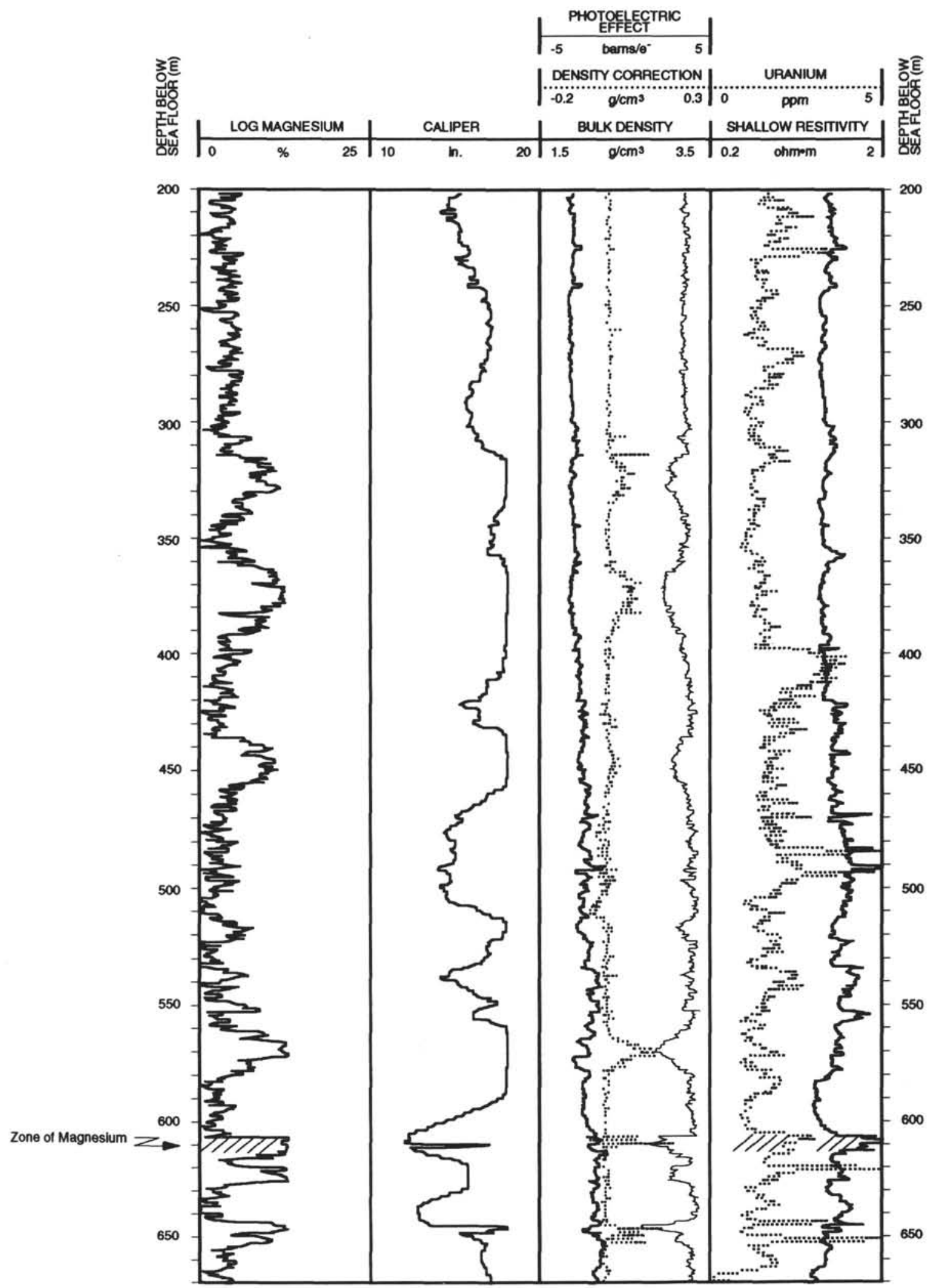

Figure 4. $\mathrm{Mg}$ calculation in Hole 817D. With the exception of the interval at $610 \mathrm{mbsf}$, the $\mathrm{Mg}$-log results seem to be governed more by the hole conditions than by the presence of dolomite. Note the increase in $\mathrm{Mg}$ opposite zones of hole washouts (caliper, density correction). 
gram outputs dry-weight percentages of $\mathrm{Al}$ and $\mathrm{K}$, which are in turn used in the calculation and normalization of the remaining elements.

\section{Normalization of Elemental Yields from the GST To Calculate the Elemental Weight Fractions}

This routine combines the dry weight percentages of $\mathrm{Al}$ and $\mathrm{K}$ with the reconstructed yields to obtain dry weight percentages of the GST elements using the relationship,

$$
W t_{i}=F Y_{i} / S_{i} \text {, }
$$

where $W t_{i}=$ absolute elemental concentration, $F=$ normalization factor, $Y_{i}=$ relative elemental yield, and $S_{i}=$ tool spectral sensitivity. The normalization factor, $F$, is a calibration factor determined at each depth from a closure argument to account for the number of neutrons captured by a specific concentration of rock elements. Because the sum of oxides in a rock is $100 \%, F$ is given by

$$
F\left(\sum_{i} X_{i} Y_{i} / S_{i}\right)+X_{\mathrm{K}} W t_{\mathrm{K}}+X_{\mathrm{Al}} W t_{\mathrm{Al}}=100,
$$

where $X_{i}=$ dry wt $\%$ of oxide or carbonate $\div$ dry wt $\%$ of element $i, Y_{i}$ $=$ fraction of spectra attributed to element $i, S_{i}=$ sensitivity factor, $X_{\mathrm{K}}$ $=$ dry $w \mathrm{t} \%$ of oxide of element $\mathrm{K} \div$ dry $\mathrm{wt} \%$ of $\mathrm{K}, W t_{\mathrm{K}}=$ dry $\mathrm{wt} \%$ of $\mathrm{K}, X_{\mathrm{Al}}=$ dry $\mathrm{wt} \%$ of oxide of element $\mathrm{Al} \div$ dry $w \mathrm{t} \%$ of $\mathrm{Al}$, and $W t_{\mathrm{Al}}$ $=$ dry $w t \%$ of $\mathrm{Al}$. The sensitivity factor, $S_{i}$, is a tool constant measured in the laboratory, which depends on the capture cross section, gammaray production, and detection probabilities of each element measured by the GST (Hertzog et al., 1989). The value $X_{i}$ accounts for the C and $\mathrm{O}$ associated with each element. Table 1 lists the oxide/carbonate factors used in this calculation.

\section{Calculation of Oxide Percentages}

The sixth and final routine simply multiplies the percentage of each element by its associated oxide/carbonate factor, using the same oxide factors as were used in the previous step (Table 1).

\section{COMPARISON OF GEOCHEMICAL LOGS TO CORE}

\section{Site 815}

The processed natural gamma-ray curves from the seismic stratigraphic run in Hole 815A are shown in Figure 5 and are compared to the lithostratigraphic units defined from core (Shipboard Scientific Party, 1991e). Because of Schlumberger computer problems on the ship, the processed natural gamma-ray logs had to be spliced to obtain the maximum amount of good data. The splice is as follows: 78 to $138 \mathrm{mbsf}$ from the downgoing $\mathrm{log}, 138$ to $218 \mathrm{mbsf}$ from the third pass of the upgoing $\log , 218$ to $263 \mathrm{mbsf}$ from the downgoing log, 263 to $338 \mathrm{mbsf}$ from the second pass of the upgoing log, 338 to 368 mbsf from the downgoing log, 368 to $457 \mathrm{mbsf}$ from the first pass of the upgoing log.

The oozes of lithostratigraphic Unit IIA are distinguished from the oozes of Unit IIB by lower $\mathrm{K}_{2} \mathrm{O}$ and Th contents. The $\mathrm{K}_{2} \mathrm{O}$ and Th logs are seen roughly to track each other in Unit IIB, indicating that the clays in these lithologies contain both elements. Within Subunit IIB, the color cycles described in the cores may be seen in these two curves, as the variation of $\mathrm{K}_{2} \mathrm{O}$ and Th often reflects clay content. The chalks of Units III and IV cannot be distinguished on these logs, as their chemical composition resembles that of lithologies of Unit II.

Figure 6 displays the oxide weight fractions estimated from the logs from Hole $815 \mathrm{~A}$, as well as calculated statistical uncertainties (plus and minus one standard deviation) of each element (Grau et al., 1990; Schweitzer et al., 1988). This error is strongly related to the normalization factor, which is calculated at each depth (Eq. 3), and is displayed with the logs to the far right. A lower normalization factor represents better counting statistics (more signal from the formation) and, therefore, higher quality data.

Core measurements of $\mathrm{CaCO}_{3}$ are displayed as solid circles and show good agreement with the logs. The nannofossil ooze of Subunit IIB shows a slightly lower $\mathrm{CaCO}_{3}$ content and a higher $\mathrm{Al}_{2} \mathrm{O}_{3}$ content than the foraminifer nannofossil and nannofossil foraminifer chalk of Subunit IIIA.

\section{Site 817}

The processed natural gamma-ray logs from Hole 817D (Fig. 7) come from the geochemical tool string. The logs were recorded through pipe from 0 to $116 \mathrm{mbsf}$ and have not been corrected for pipe attenuation. The gamma-ray logs display very low values in this well; however, sharp increases in total gamma-ray content due to the presence of U occur in the top of Unit IIA and the middle of Unit IIB. The top and the bottom of Subunit IIC are characterized by small increases in $\mathrm{U}$, the latter possibly correlating with a zone of bioturbated clasts observed at the bottom of the unit. Dolomite is noted in the cores of Unit III, marked by an overall positive shift in U, as would be expected in a dolomitic lithology. Pronounced spikes in the U curve may indicate lenses that are more dolomitized.

The oxide weight fractions, with uncertainties for Hole 817D, are shown in Figure 8. Note that the actual log value of $\mathrm{SiO}_{2}$ is zero; the standard was not included in the best-fit analysis processing step, as the $\mathrm{Si}$ content was below the resolution of the tool, and the inclusion of this standard induced noise into the other elements. The error logs, which create the shaded interval, have been added. $\mathrm{CaCO}_{3}$ measurements from core show excellent agreement with the logs in this hole. $\mathrm{The} \mathrm{FeO} *(\mathrm{FeO} *$ is $\mathrm{Fe}$ expressed with an oxide factor produced from the average of the oxide factors of $\mathrm{FeO}$ and $\left.\mathrm{Fe}_{2} \mathrm{O}_{3}\right), \mathrm{Al}_{2} \mathrm{O}_{3}$, and $\mathrm{Gd}$ curves all show slightly higher values in the oozes of Unit I than in the chalk of Unit II. Dolomitization increases downsection in Unit III; the oxide logs, however, do not show any change, because the chemical compositions of the measured elements are similar.

\section{Site 820}

The processed natural gamma-ray logs from the geochemical tool string recorded at Hole $820 \mathrm{~B}$ are displayed in Figure 9. The upper 70 $\mathrm{m}$ of $\log$ data was recorded through pipe, and corrections have been attempted to account for attenuation in the logs. Because the boundary between Subunits IA and IB occurs between the open-hole and through-pipe logs, any interpretation of character change in the logs is not truly valid in this interval.

The oxide weight fractions for Hole $820 \mathrm{~B}$ and discrete carbonate core analyses are shown in Figure 10 . The $\mathrm{CaCO}_{3}$ core measurements agree well with the $\mathrm{CaCO}_{3} \log$ measurements. The $\mathrm{CaCO}_{3} \log$ clearly delineates the coarsening-upward cycles within Unit II and to a lesser extent within Unit III. The $\mathrm{CaCO}_{3}$ character is inversely related to the $\log$ character of $\mathrm{SiO}_{2}, \mathrm{FeO}^{*}, \mathrm{Al}_{2} \mathrm{O}_{3}, \mathrm{~K}_{2} \mathrm{O}$, and $\mathrm{Th}$, indicating that clays play an important role in the cycles and carbonate content of the formation. The cycles are not as clearly distinguished in Unit III, possibly due to an increase of bioturbation within this unit.

\section{Site 822}

Figure 11 displays the processed natural gamma-ray logs recorded in Hole 822A. The upper $70 \mathrm{~m}$ of data was recorded through pipe, and corrections for attenuation have been made. The total gamma-ray content is lower in Unit I than in Unit II, due to a decrease in U content in this upper unit. The variation in and overall content of $\mathrm{K}_{2} \mathrm{O}$ increase slightly in Unit II, perhaps because of an increase in terrigenous influx. 

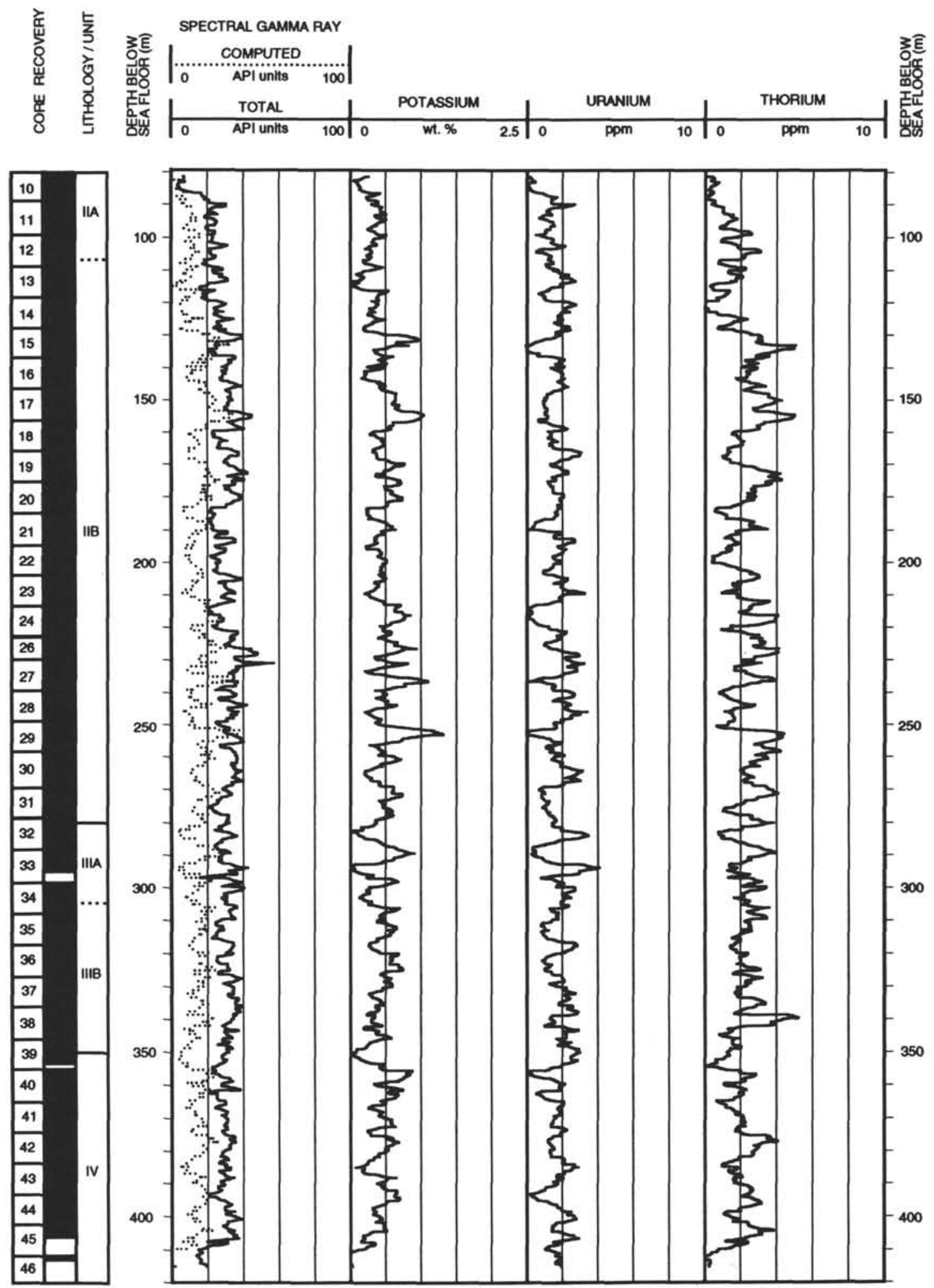

\section{HOLE 815A: LEGEND OF LITHOLOGIC UNITS/SUBUNITS}

Subunit IIA:Foraminifer nannofossil and nannofossil foraminifer ooze

Subunit IIB: Nannofossil ooze and clayey nannofossil mixed sediment

Subunit IIIA: Foraminifer nannofossil and nannofossil foraminifer chalks

Subunit IIIB: Foraminifer nannofossil and nannofossil foraminifer chalks

Unit IV: Foraminifer nannofossil and nannofossil foraminifer chalks

Figure 5. Processed natural gamma-ray data, Hole 815A. Subunit IIA: foraminifer nannofossil and nannofossil foraminifer ooze; Subunit IIB: nannofossil ooze and clayey nannofossil mixed sediment; Subunit IIIA: foraminifer nannofossil and nannofossil foraminifer chalks; Subunit IIIB: foraminifer nannofossil and nannofossil foraminifer chalks; Unit IV: foraminifer nannofossil and nannofossil foraminifer chalks. 

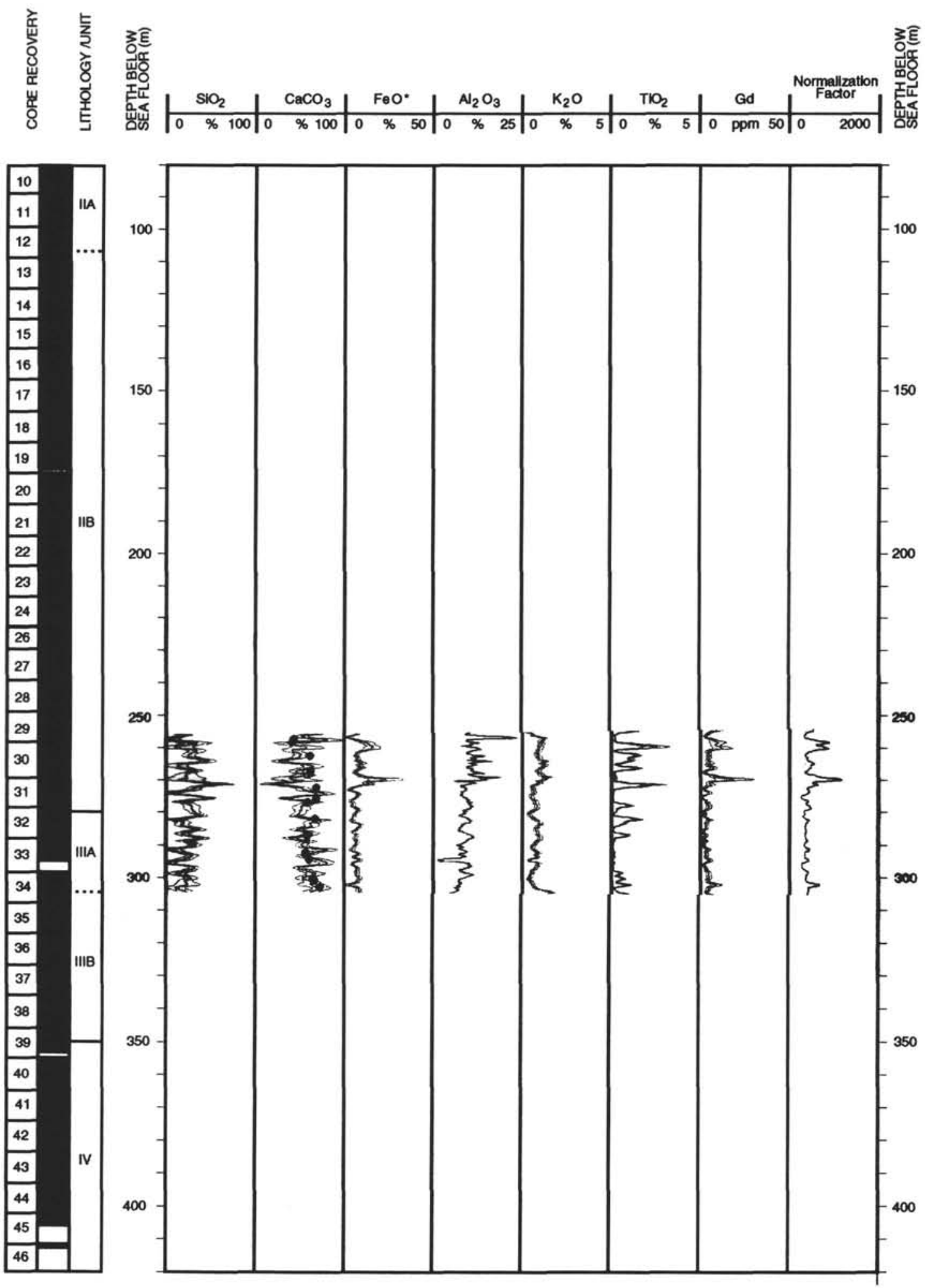

Figure 6. Estimates of calcium carbonate and major oxide weight fractions from geochemical logs, Hole 815A. Solid circles represent carbonate values from core measurements (Shipboard Scientific Party, 1991e). Lithologic units are listed in Figure 5 caption. 
Figure 12 displays the oxide weight fractions from the logs along with carbonate core analyses for Hole $822 \mathrm{~A}$. The hole conditions in Hole $822 \mathrm{~A}$ were the most variable of any of the holes logged, and, therefore, the oxide results are greatly affected. The normalization factor curve (a quality control curve discussed previously), displayed to the right of the logs, is highly variable and strongly influences the character of the $\mathrm{FeO}^{*}$ and $\mathrm{Gd}$ curves, which in turn affect all of the other logs in the normalization process. The $\mathrm{CaCO}_{3} \log$ does, however, correlate well with the core measurements and can be used in interpreting variations in carbonate vs. clay content of the hole.

\section{Site $\mathbf{8 2 3}$}

The processed natural gamma-ray curves for Hole $823 \mathrm{C}$ are displayed in Figure 13. The upper $178 \mathrm{~m}$ were recorded through pipe and attenuation corrections have been made to account for this.

The oxide weight fractions are displayed in Figure 14 with the carbonate core measurements. Corrections for pipe attenuation above 166 mbsf have been applied. In this zone, however, the results are considered valid from a qualitative standpoint only, even though the carbonate log measurements show excellent agreement with core throughout most of the hole.

Units I and II are not distinguishable in the logs because the chemical composition of the two units is similar. Unit III is also similar in composition; however, a marked increase in log variation (particularly the $\mathrm{FeO} *, \mathrm{Al}_{2} \mathrm{O}_{3}$, and $\mathrm{K}_{2} \mathrm{O} \operatorname{logs}$ ) is seen within Subunit IIIA.

A decrease in carbonate content, seen at the top of Unit IV, along with an increase in $\mathrm{Al}_{2} \mathrm{O}_{3}, \mathrm{~K}_{2} \mathrm{O}$, and $\mathrm{Th}$, reflects an increase in clay content within the upper part of this unit. Unit $\mathrm{V}$ is described as dark-colored nannofossil mixed sediment to nannofossil claystone. Carbonate content decreases in this unit as $\mathrm{SiO}_{2}$ content increases and as $\mathrm{Al}_{2} \mathrm{O}_{3}, \mathrm{~K}_{2} \mathrm{O}$, and Th values elevate slightly. Unit $\mathrm{VI}$ is described as alternating light- and dark-colored chalks. The logs indicate that the uppermost and lowermost parts of this unit are dominated by the light-colored chalks (high carbonate content), while the middle part of this unit is dominated by dark-colored chalks (higher $\mathrm{K}_{2} \mathrm{O}$ and Th values). A gradual increase in clay content is suggested in the logs within Unit VII by a gradual decrease in $\mathrm{CaCO}_{3}$ content and an increase in $\mathrm{FeO}^{*}$ and Th contents.

\section{SUMMARY AND CONCLUSIONS}

The reprocessing of natural gamma-ray logs improves the measurements obtained in the field by incorporating environmental corrections (e.g., for hole size, type of drilling fluid, etc.) and better calibrations of Th, $\mathrm{U}$, and $\mathrm{K}$.

Geochemical logs, converted to elemental and oxide measurements, compare well with the carbonate core data in the open-hole sections. The general trends of $\mathrm{CaCO}_{3}$ logs were found to be particularly useful in portraying increases or decreases in carbonate vs. clay contents. Adetailed study of changes in the logs may be useful in tying interpretation of sequence stratigraphy and changes in sea level.

We have concluded that the $\mathrm{Mg}$ calculation does not work properly in ODP holes. Because the calculation is affected more by adverse hole conditions than by actual $\mathrm{Mg}$ content, the inclusion of this calculation in the normalization induces noise into all of the other measured elements.

\section{ACKNOWLEDGMENTS}

The authors would like to thank Jennifer Tivy for her critical reviews of the manuscript and her work in creating the final figures.

\section{REFERENCES}

Grau, J.A., and Schweitzer, J.S., 1989. Elemental concentrations from thermal neutron capture gamma-ray spectra in geological formations. $\mathrm{Nucl}$. Geophys., 3:1-9.

Grau, J.A., Schweitzer, J.S., and Hertzog, R.C., 1990. Statistical uncertainties of elemental concentrations extracted from neutron induced gamma-ray measurements. IEEE Trans. Nucl. Sci., 37:2175-2178.

Hertzog, R., Colson, L., Seeman, B., O'Brien, M., Scott, H., McKeon, D., Wraight, J., Grau, J., Ellis, D., Schweitzer, J., and Herron, M., 1989. Geochemical logging with spectrometry tools. SPE Form. Eval., 4:153-162.

Lock, G.A., and Hoyer, W.A., 1971. Natural gamma-ray spectral logging. Log Analyst, 12:3-9.

Ruckebusch, G., 1983. A Kalman filtering approach to natural gamma ray spectroscopy in well logging. IEEE Trans. Autom. Control, AC-28:372-380.

Schweitzer, J.S., Grau, J.A., and Hertzog, R.C., 1988. Precision and accuracy of short-lived activation measurements for in situ geological analyses. $J$. Trace Microprobe Techn., 6:437-451.

Scott, H.D., and Smith, M.P., 1973. The aluminum activation log. Log Analyst, 14:3-12.

Shipboard Scientific Party, 1991a. Principal results and summary. In Davies, P.J., McKenzie, J.A., Palmer-Julson, A., et al., Proc. ODP, Init. Repts., 133: College Station, TX (Ocean Drilling Program), 59-72.

1991b. Site 812. In Davies, P.J., McKenzie, J.A., Palmer-Julson, A., et al., Proc. ODP, Init. Repts., 133: College Station, TX (Ocean Drilling Program), 135-176.

1991c. Site 813. In Davies, P.J., McKenzie, J.A., Palmer-Julson, A., et al., Proc. ODP, Init. Repts., 133: College Station, TX (Ocean Drilling Program), 177-202.

1991d. Site 814. In Davies, P.J., McKenzie, J.A., Palmer-Julson, A., et al., Proc. ODP, Init. Repts., 133: College Station, TX (Ocean Drilling Program), 203-242.

1991e. Site 815. In Davies, P.J., McKenzie, J.A., Palmer-Julson, A., et al., Proc. ODP, Init. Repts., 133: College Station, TX (Ocean Drilling Program), 243-300.

1991f. Site 817. In Davies, P.J., McKenzie, J.A., Palmer-Julson, A., et al., Proc. ODP, Init. Repts., 133: College Station, TX (Ocean Drilling Program), 345-416.

1991g. Site 820. In Davies, P.J., McKenzie, J.A., Palmer-Julson, A., et al., Proc. ODP, Init. Repts., 133: College Station, TX (Ocean Drilling Program), 509-568.

1991h. Site 822. In Davies, P.J., McKenzie, J.A., Palmer-Julson, A., et al., Proc. ODP, Init. Repts., 133: College Station, TX (Ocean Drilling Program), 615-678.

, 1991i. Site 823. In Davies, P.J., McKenzie, J.A., Palmer-Julson, A., et al., Proc. ODP, Init. Repts., 133: College Station, TX (Ocean Drilling Program), 679-768.

\footnotetext{
Abbreviations for names of organizations and publication titles in ODP reference lists follow the style given in Chemical Abstracts Service Source Index (published by American Chemical Society).
}

Date of initial receipt: 17 March 1992

Date of acceptance: 2 November 1992

Ms 133SR-289 

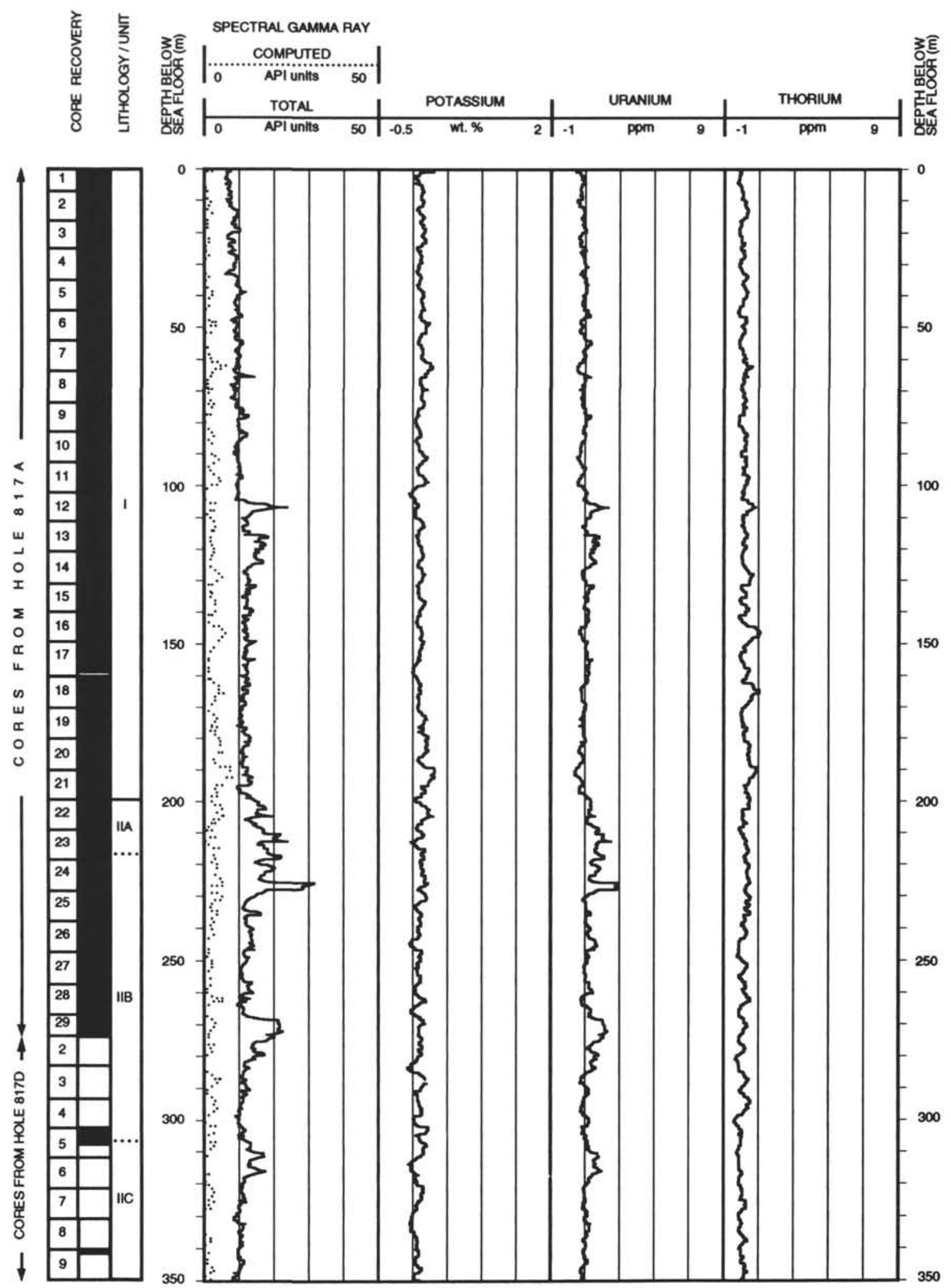

Figure 7. Processed natural gamma-ray data, Hole 817D. The lithologic legend used is common to Figures 7 and 8: Unit I: micritic ooze overlying nannofossil ooze; Subunit IIA: calcareous chalk with redeposited sediments; Subunit IIB: nannofossil chalk with foraminifers, micrite, and sponge molecules; Subunit IIC: calcareous chalk with foraminifers and bioclasts; Subunit IIIA: bioclastic and grainstone interbedded with calcareous chalk; dolomitic; Subunit IIIB: dolomitic, bioclastic packstone and grainstone; Subunit IIIC: dolomite. 

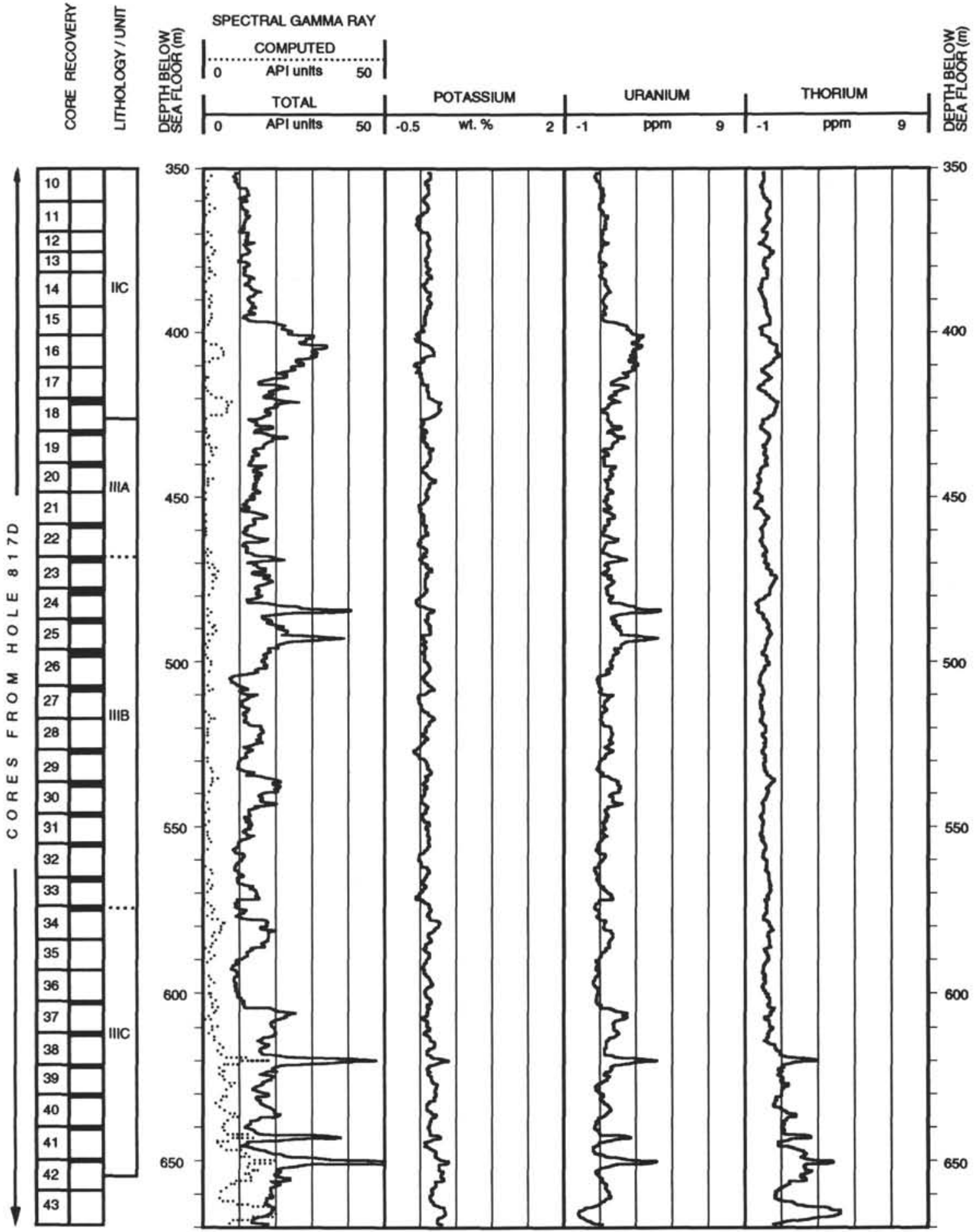

\section{HOLE 817D: LEGEND OF LITHOLOGIC UNITS/SUBUNITS}

Unit I: Micritic ooze overlying nannifossil ooze

Subunit IIA: Calcareous chalk with redeposited sediments

Subunit IIB: Nannofossil chalk with foraminifers, micrite, and sponge molecules

Subunit IIC: Calcareous chalk with foraminifers and bioclasts

Subunit IIIA: Bioclastic and grainstone interbedded with calcareous chalk; dolomitic

Subunit IIIB: Dolomitic, bioclastic packstone and grainstone

Subunit IIIC: Dolomite

Figure 7 (continued). 

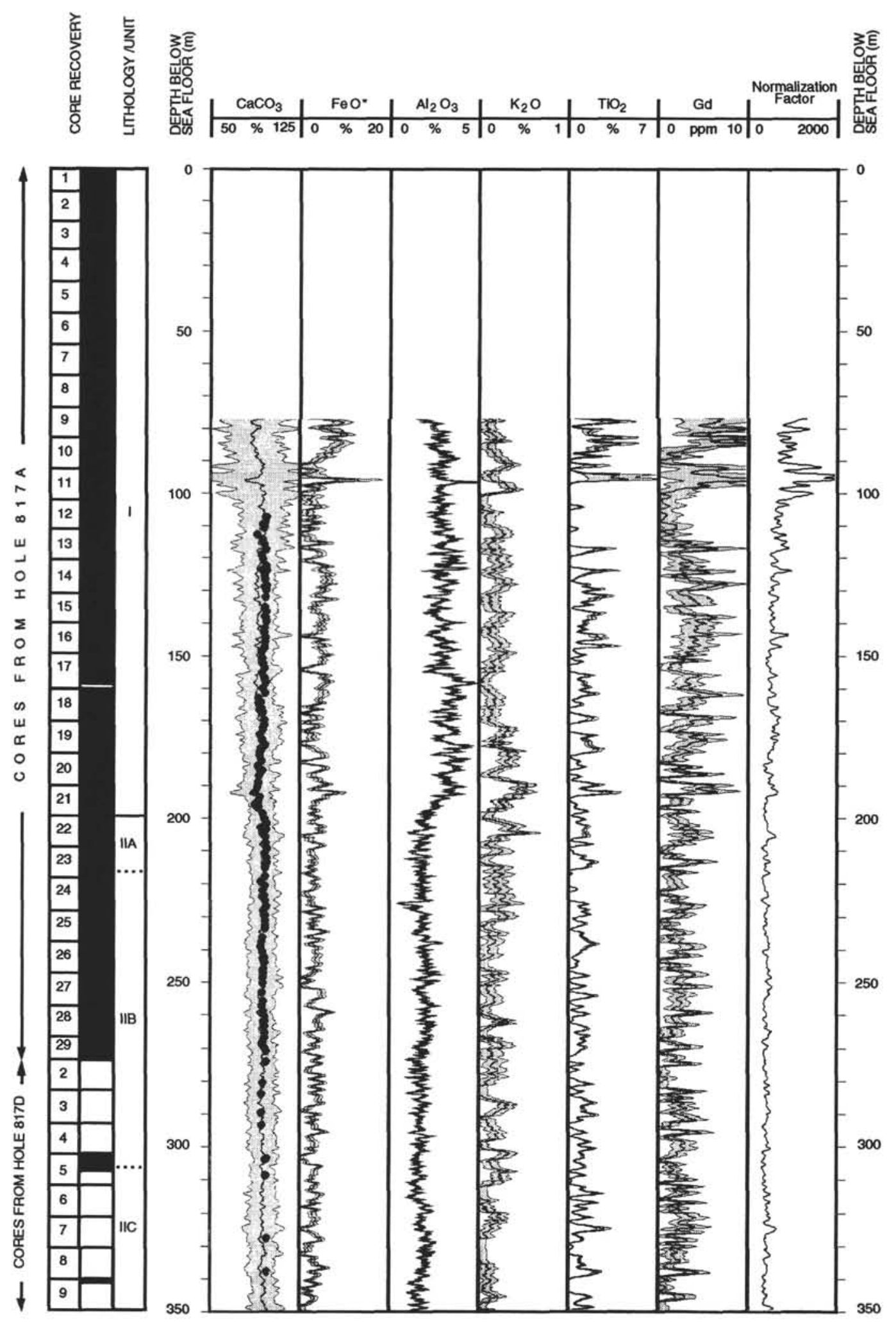

Figure 8. Calcium carbonate and major oxide weight fractions from geochemical logs run in Hole 817D compared with carbonate core measurements (Shipboard Scientific Party, 1991f). 

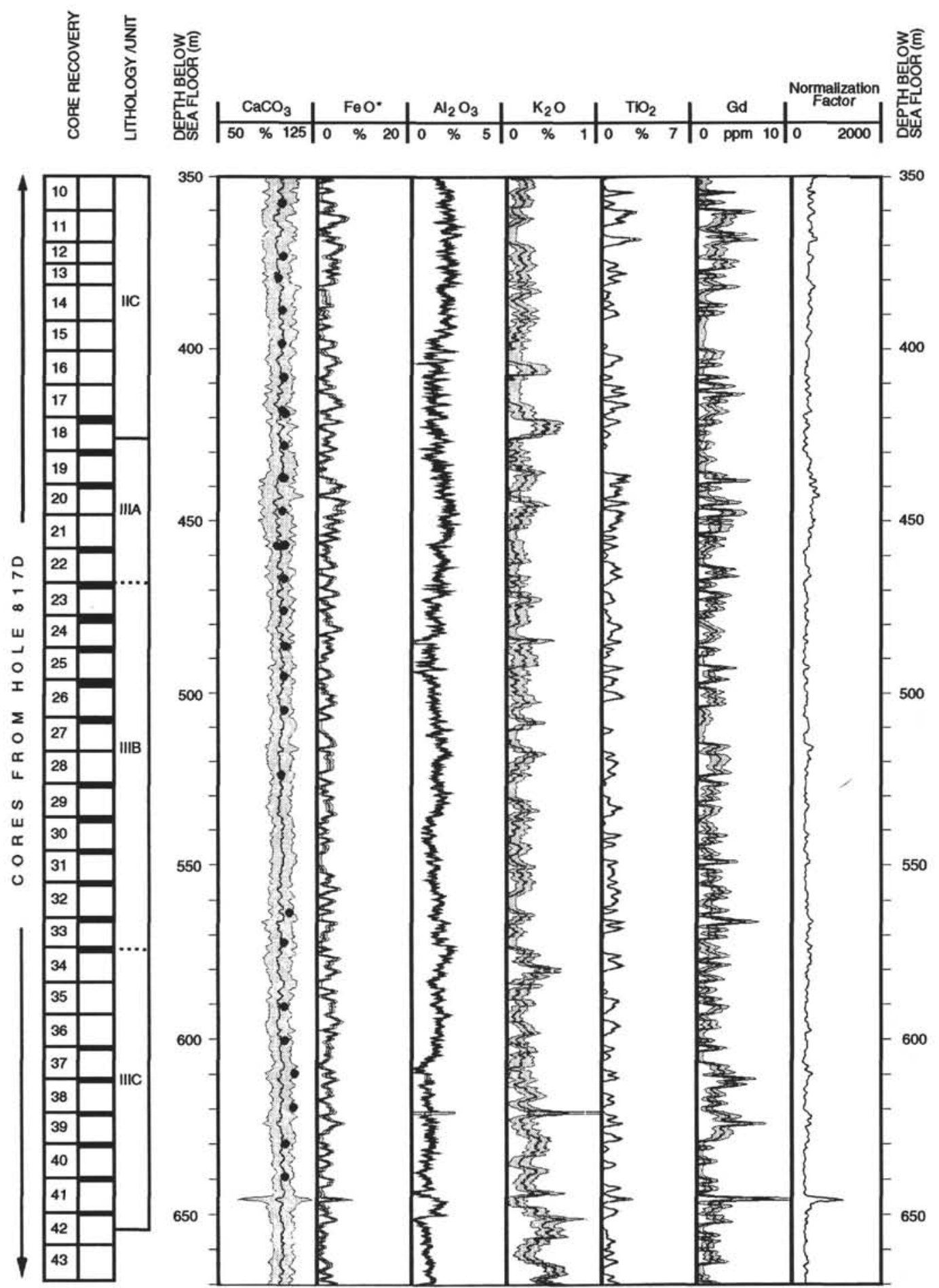

Figure 8 (continued). 

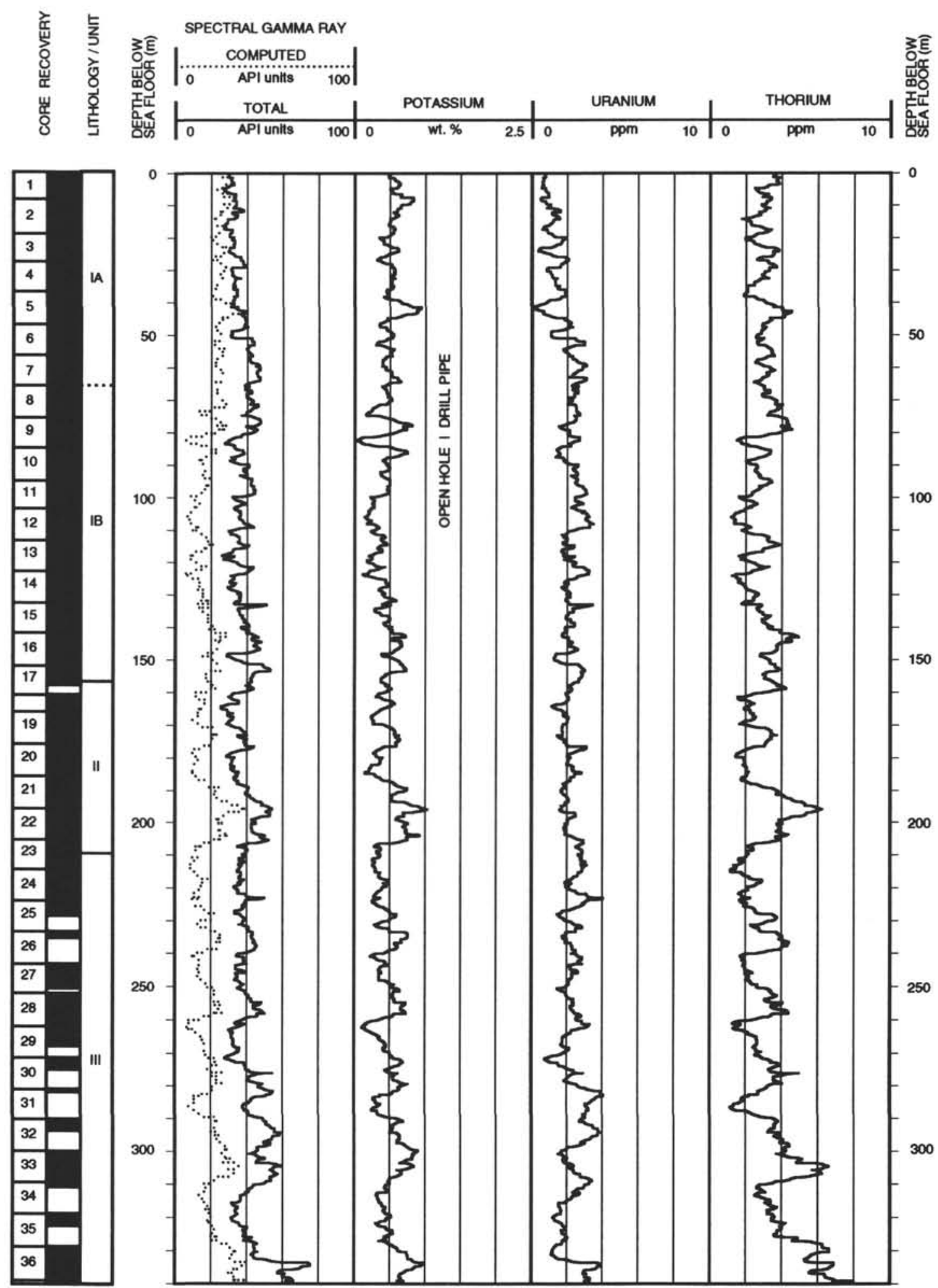

\section{HOLE 820B: LEGEND OF LITHOLOGIC UNITS/SUBUNITS}

Subunit IA: Clayey wackestone with bioclastic wackestone/packstone

Subunit IB: Carbonate-rich clayey wackestone with bioclastic wackestone/packstone

Unit II: Upward-coarsening cycles; clayey mixed sediment grading upward to nannofossil calcitic

wackestone/packstone

Unit III: Upward-coarsening cycles; sediment and calcareous mudstone grading upward to bioclastic packstone

Figure 9. Processed natural gamma-ray data, Hole 820B. The lithologic legend used is common to Figures 9 and 10: Subunit IA: Clayey wackestone with bioclastic wackestone/packstone; Subunit IB: carbonate-rich clayey wackestone with bioclastic wackestone/packstone; Unit II: upward-coarsening cycles; clayey mixed sediment grading upward to nannofossil calcitic wackestone/packstone; Unit III: upward-coarsening cycles; sediment and calcareous mudstone grading upward to bioclastic packstone. 

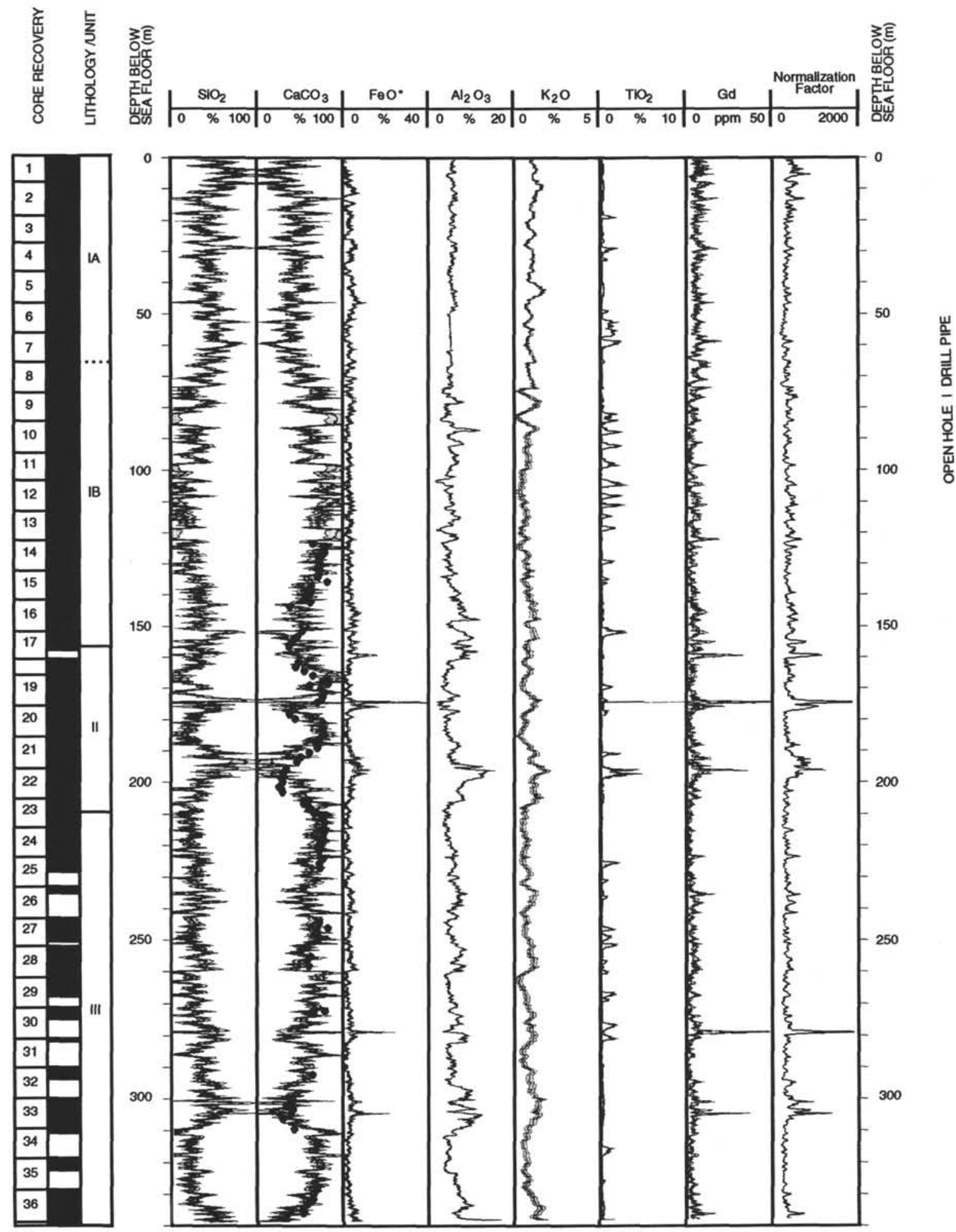

Figure 10. Calcium carbonate and major oxide weight fractions from geochemical logs run in Hole 820B compared with carbonate core measurements (Shipboard Scientific Party, 1991g). 

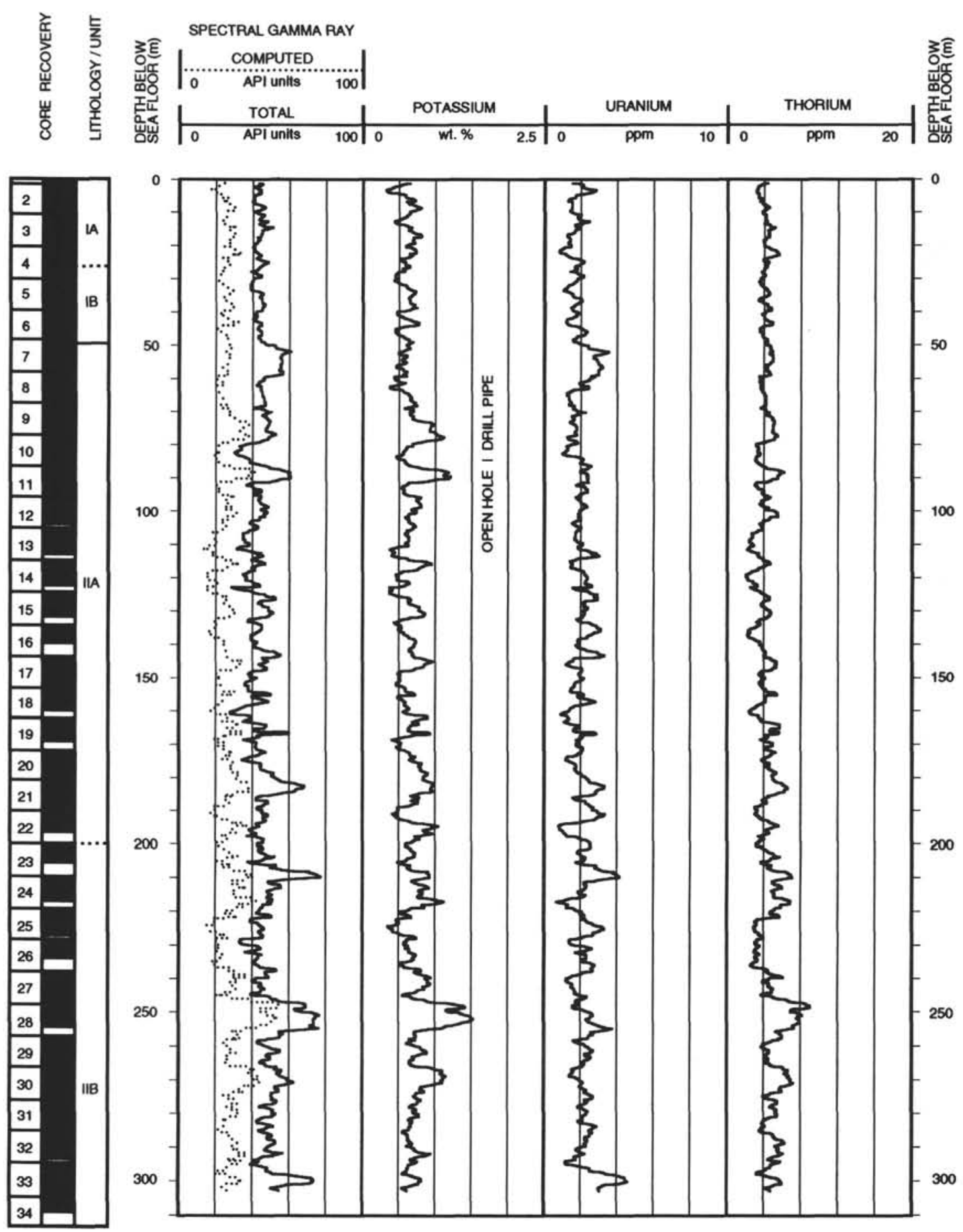

\section{HOLE 822B: LEGEND OF LITHOLOGIC UNITS/SUBUNITS}

Subunit IA: Clayey bioclastic ooze with nannofossils and micrite Subunit IB: Clayey nannofossil ooze with bioclasts

Subunit IIA: Clayey to silty mixed sediment with nannofossils and bioclasts

Subunit IIB: Calcareous claystone and clayey to silty nannofossil mixed sediment with bioclasts and quartz

Figure 11. Processed natural gamma-ray data, Hole 822A. The lithologic legend used is common to Figures 11 and 12: Subunit IA: clayey bioclastic ooze with nannofossils and micrite; Subunit IB: clayey nannofossil ooze with bioclasts; Subunit IIA: clayey to silty mixed sediment with nannofossils and bioclasts; Subunit IIB: calcareous claystone and clayey to silty nannofossil mixed sediment with bioclasts and quartz. 

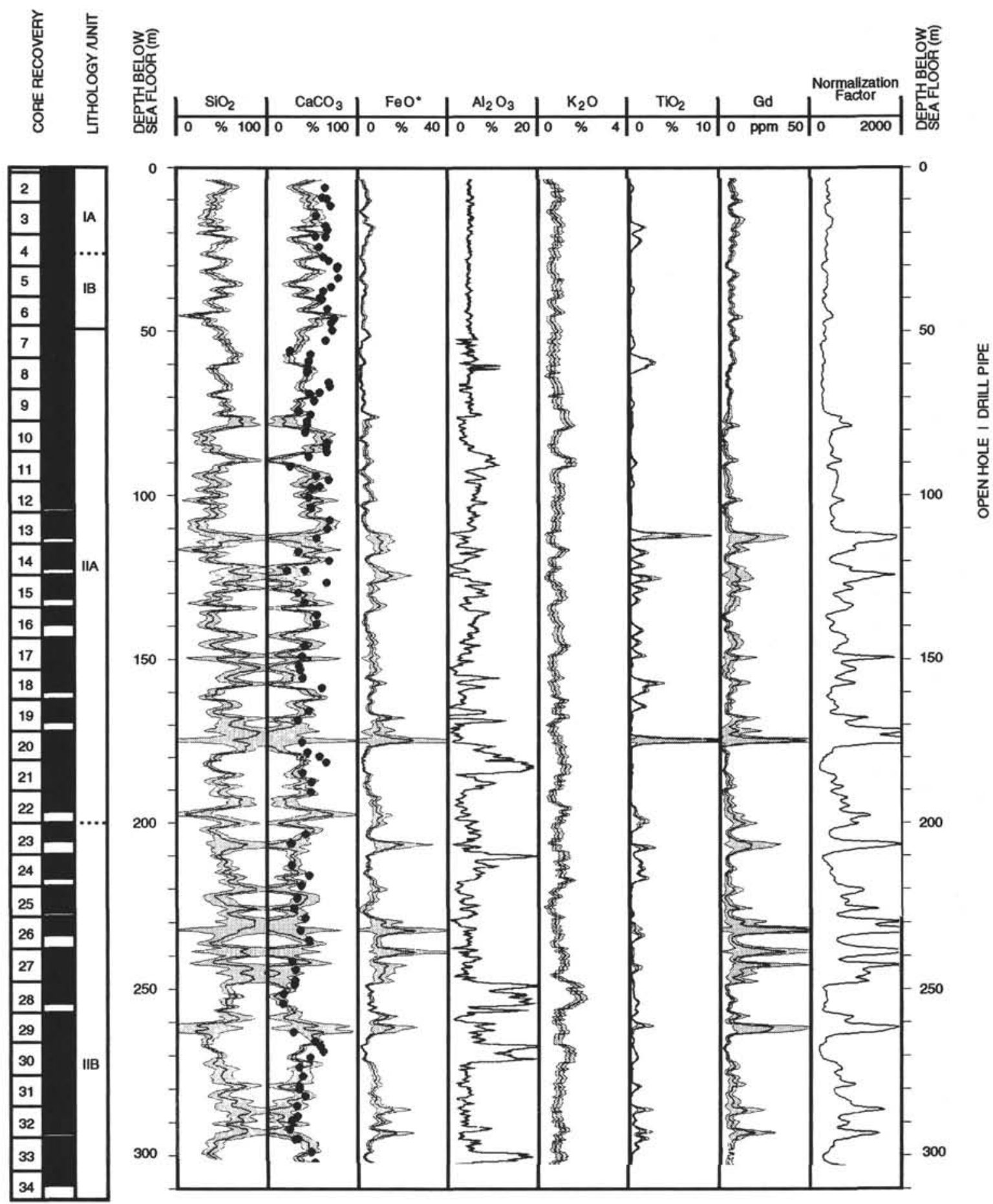

Figure 12. Calcium carbonate and major oxide weight fractions from geochemical logs run in Hole $822 \mathrm{~A}$ compared with carbonate core measurements (Shipboard Scientific Party, 1991h). 

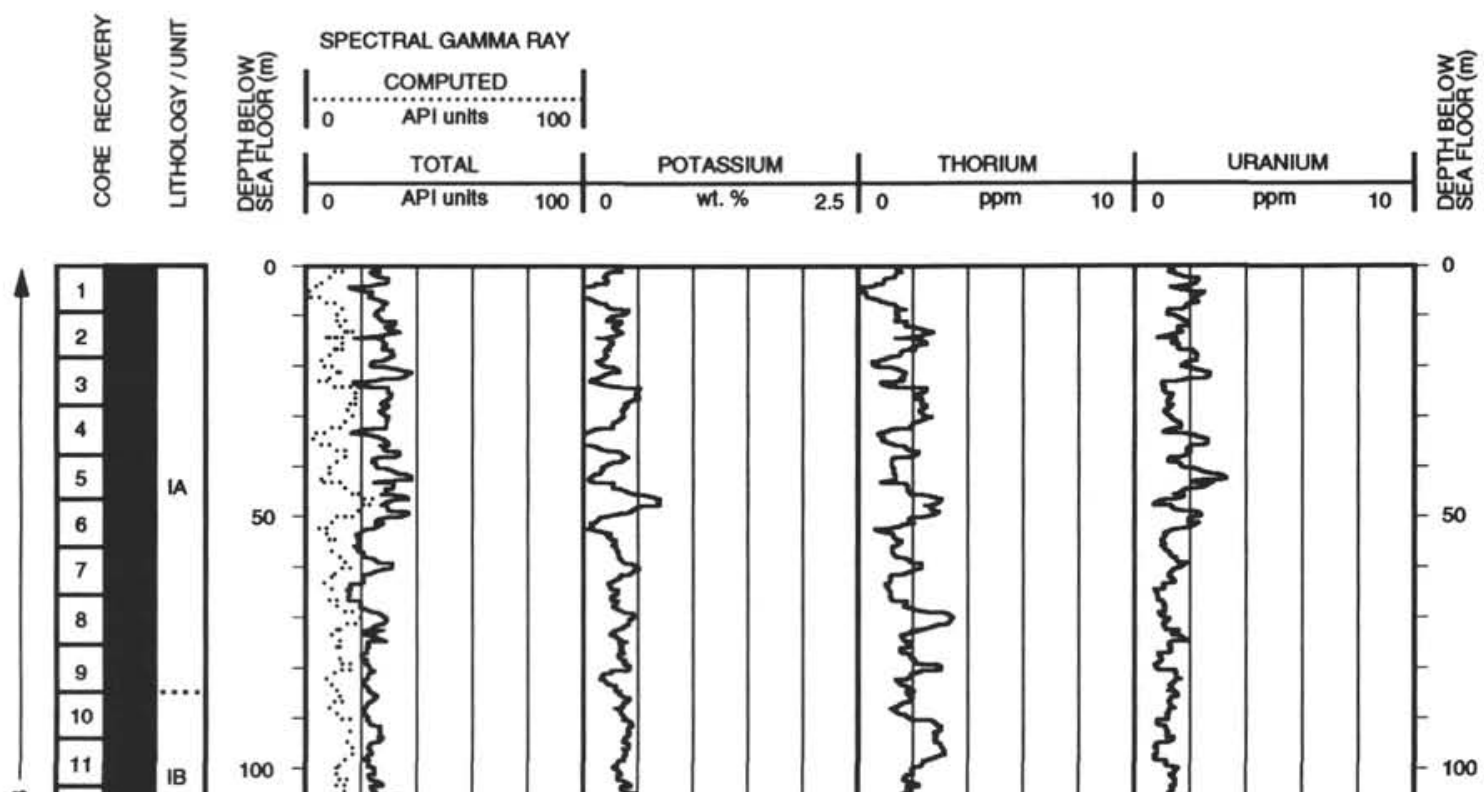

$\infty$

$m$

N

$\infty$

w

$+$

0

I

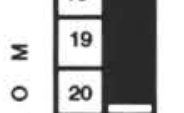

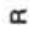

$u$

$n$

w

다

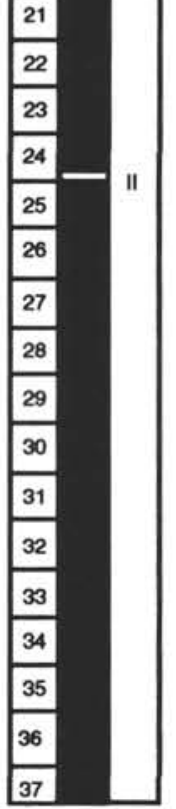

100
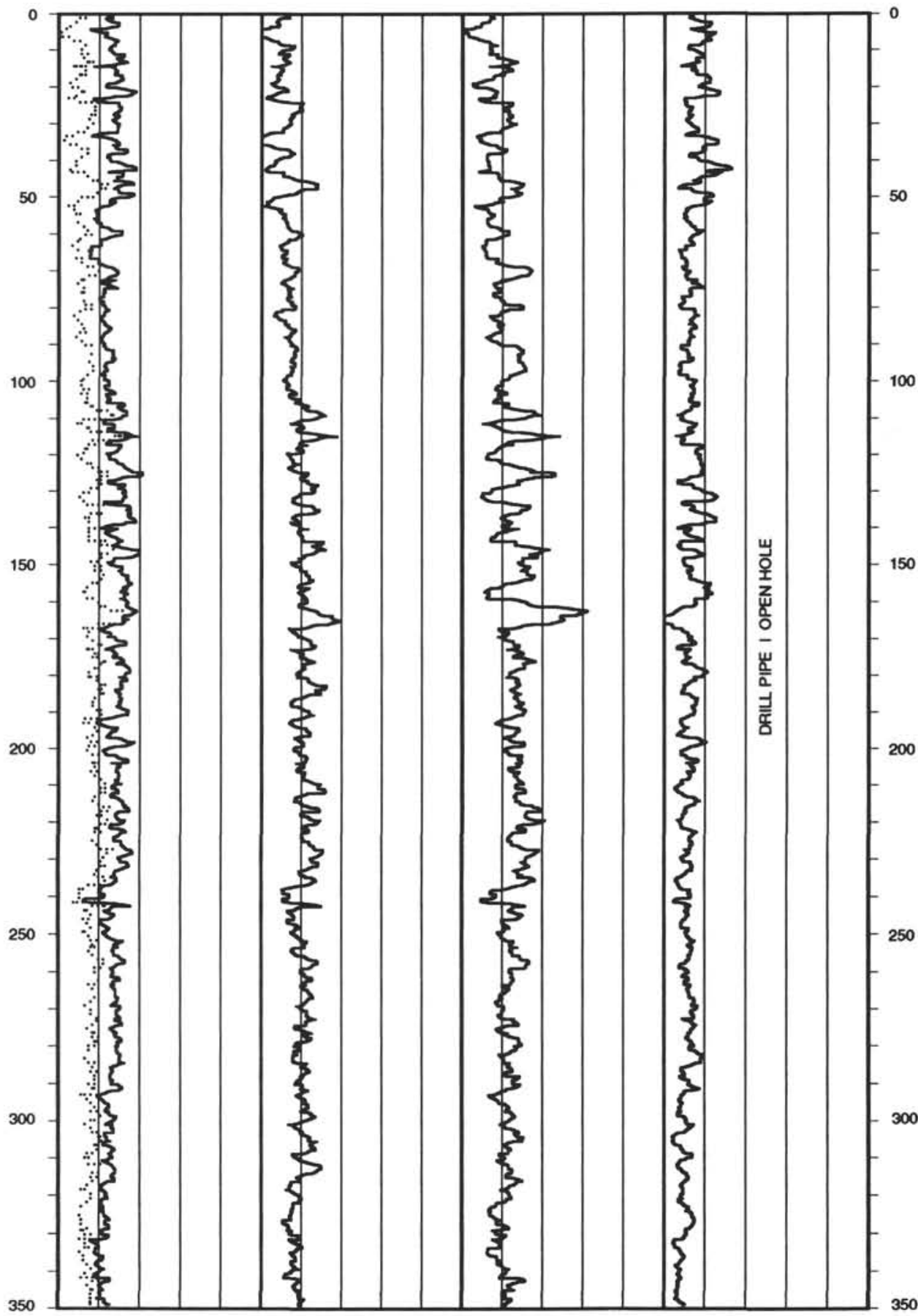

Figure 13. Processed natural gamma-ray data, Hole 823C. The lithologic legend used is common to Figures 13 and 14: Subunit IA: nannofossil ooze to mixed sediments; Subunit IB: claystone with nannofossils to nannofossil mixed sediments; Unit II: nannofossil ooze/chalk to clayey nannofossil ooze; Subunit IIIA: nannofossil chalk to clayey nannofossil mixed sediments to dolomitic nannofossil mixed sediments to dolomitic nannofossil chalk with clay; Subunit IIIB: nannofossil chalk to mixed sediments with bioclastic packstone and siliciclastics; Subunit IIIC: nannofossil chalk to mixed sediment with mudclasts; Unit IV: nannofossil chalk to mixed sediment; mixed sediments to claystones increasing with depth; Unit V: nannofossil mixed sediment to nannofossil claystone with foraminifer skeletal packstones; Unit VI: alternating chalk with clay-rich chalk and skeletal packstone; Unit VII: nannofossil chalk to nannofossil claystone with lithoclastic rudstone, bioclastic packstone, and quartz foraminifer packstone. 

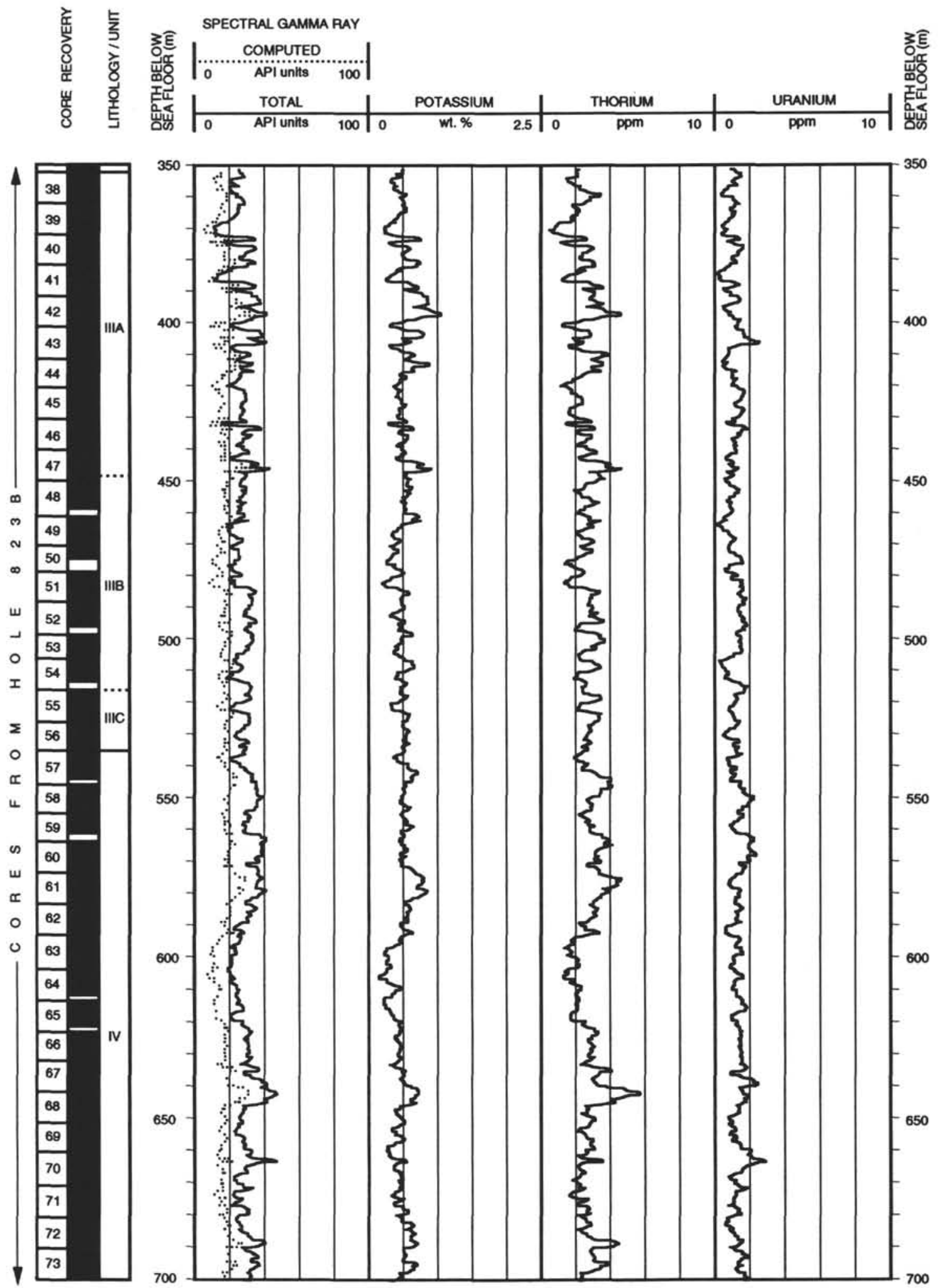

Figure 13 (continued). 


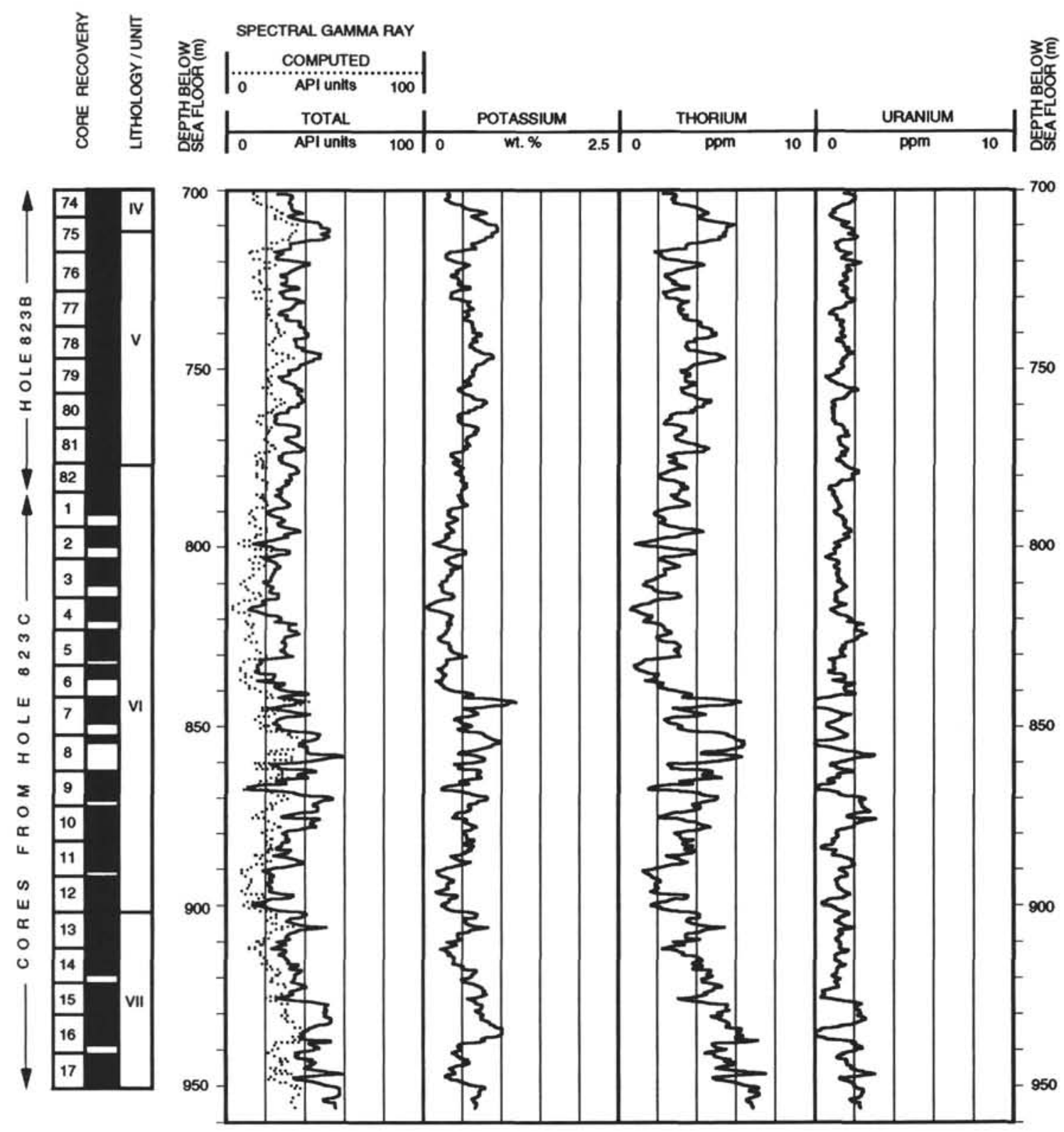

HOLE 823C: LEGEND OF LITHOLOGIC UNITS/SUBUNITS

Subunit IA: Nannofossil ooze to mixed sediments

Subunit IB: Claystone with nannofossils to nannofossil mixed sediments

Unit II: Nannofossil ooze/chalk to clayey nannofossil ooze

Subunit IIIA: Nannofossil chalk to clayey nannofossil mixed sediments to dolomitic nannofossil mixed

sediments to dolomitic nannofossil chalk with clay

Subunit IIIB: Nannofossil chalk to mixed sediments with bioclastic packstone and siliciclastics

Subunit IIIC: Nannofossil chalk to mixed sediment with mudclasts

Unit IV: Nannofossil chalk to mixed sediment; mixed sediments to claystones increasing with depth

Unit V: Nannofossil mixed sediment to nannofossil claystone with foraminifer skeletal packstones

Unit Vl: Alternating chalk with clay-rich chalk and skeletal packstones

Unit VII: Nannofossil chalk to nannofossil claystone with lithoclastic rudstone, bioclastic packstone, and quartz formainifer packstone.

Figure 13 (continued). 

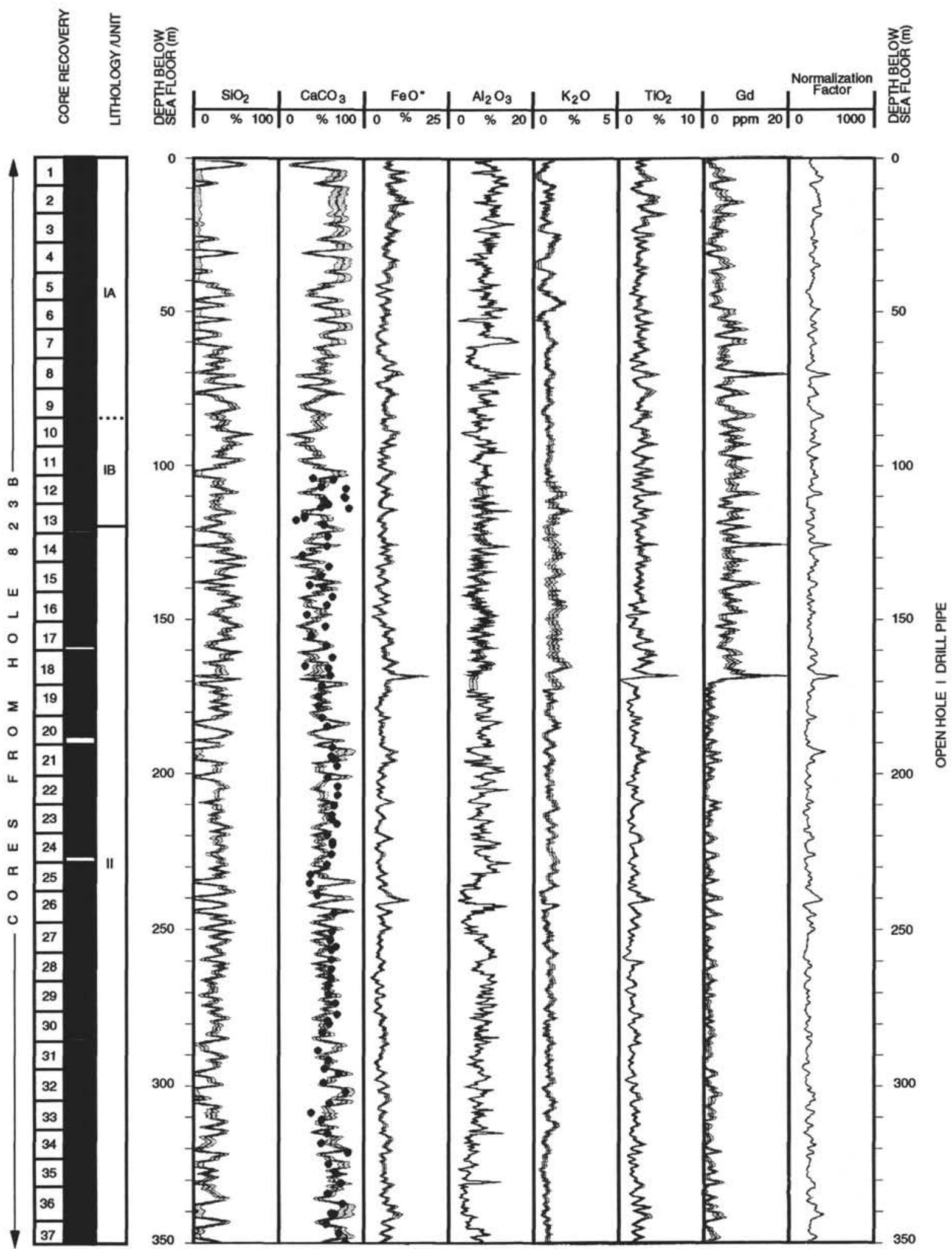

Figure 14. Calcium carbonate and major oxide weight fractions from geochemical logs run in Hole $823 \mathrm{C}$ compared with carbonate core measurements (Shipboard Scientific Party, 1991i). 


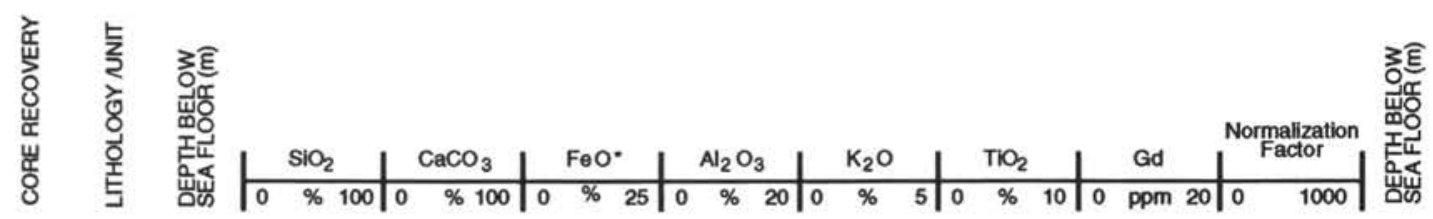
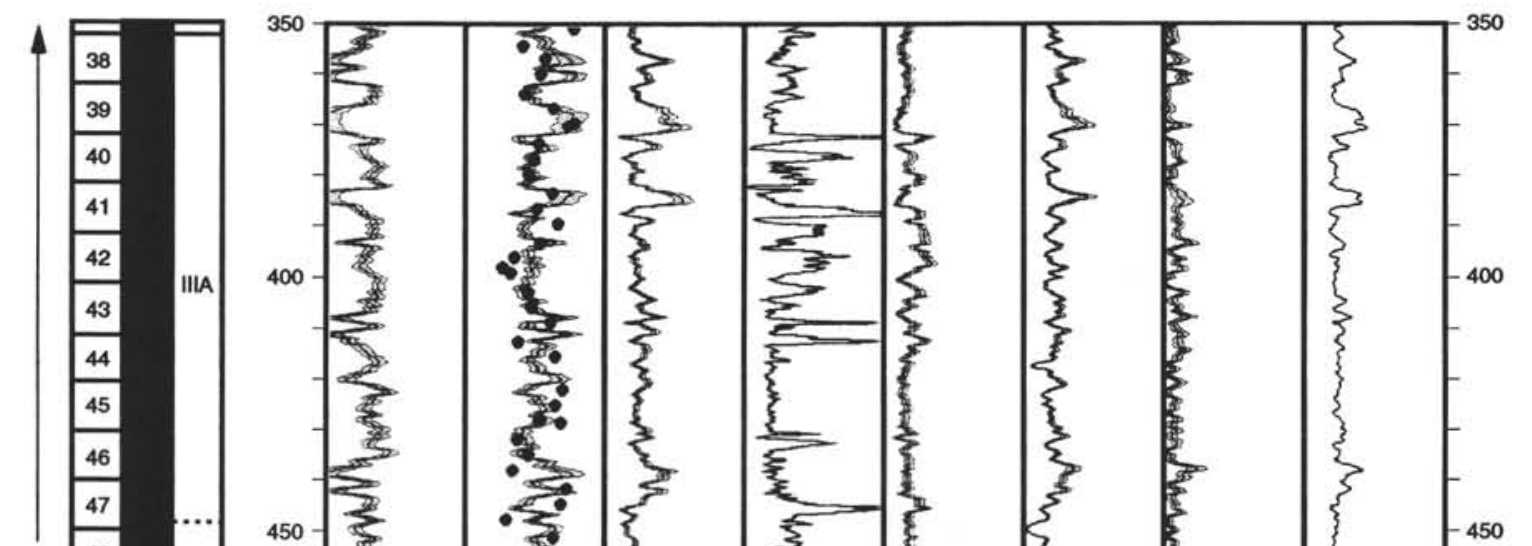

$\infty$

N

ш

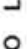

I

$\Sigma$

0

a

$u$

แ

○

0

|

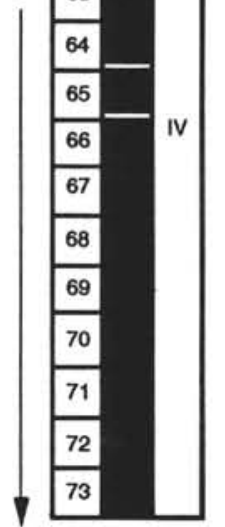
F

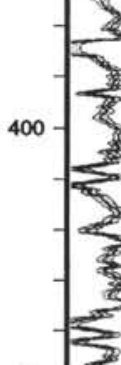

$450-\frac{3}{3}$

49

50

52

53

. ....

\begin{tabular}{|l|}
55 \\
\hline 56
\end{tabular}

57

\begin{tabular}{|l|}
\hline 58 \\
\hline 59
\end{tabular}

60

61

62

63

Figure 14 (continued). 

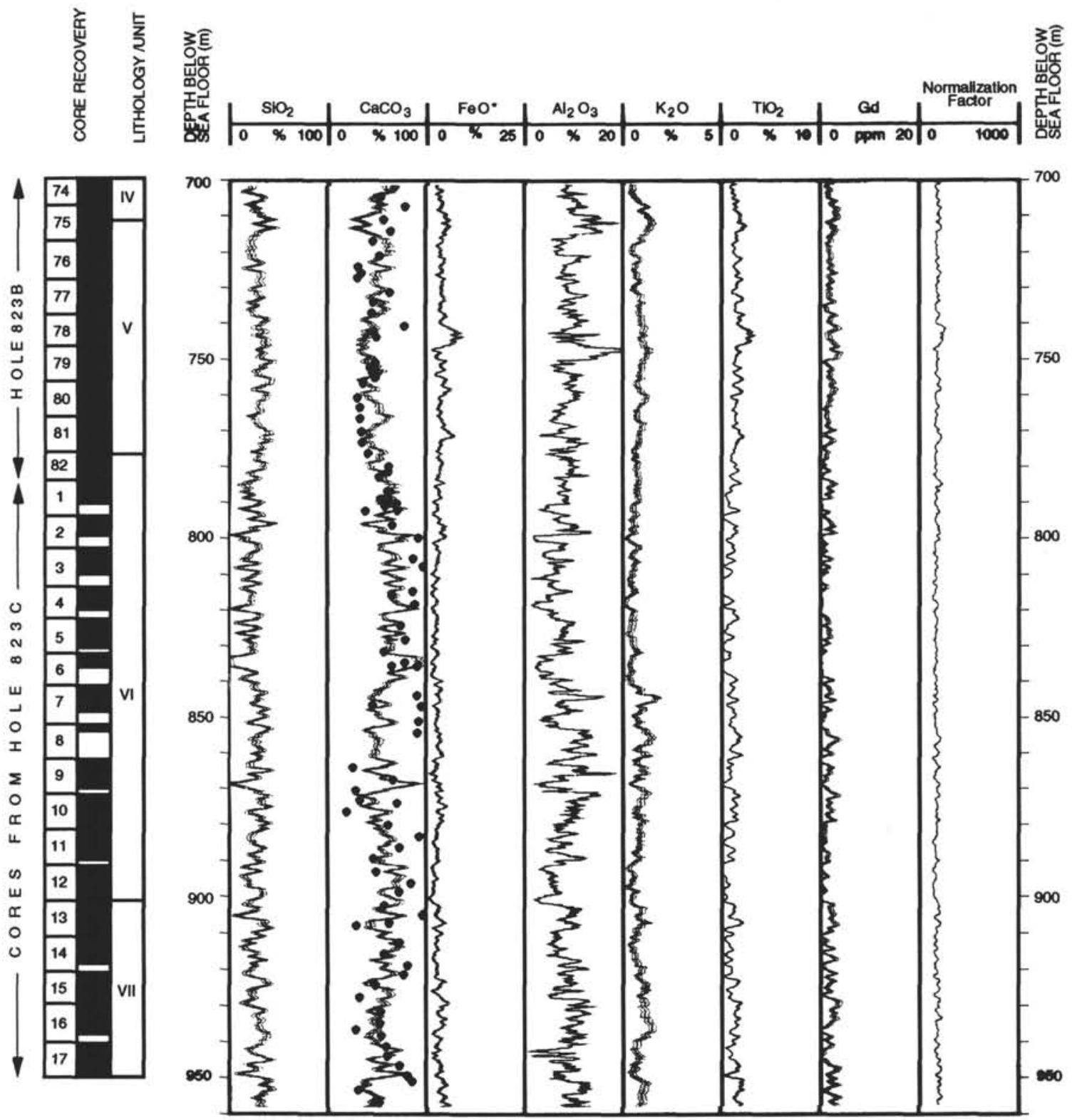

Figure 14 (continued). 